\title{
The therapeutic applications of mesenchymal stromal cells from human perinatal tissues in autoimmune diseases
}

\author{
Chao Yang ${ }^{1 *}$ D, Mingjun Wu ${ }^{1}$, Min You', Yu Chen ${ }^{1}$, Maowen Luo ${ }^{1}$ and Qiang Chen ${ }^{1,2^{*}}$
}

\begin{abstract}
The autoimmune diseases are characterized by overactivation of immune cells, chronic inflammation, and immune response to self-antigens, leading to the damage and dysfunction of multiple organs. Patients still do not receive desired clinical outcomes while suffer from various adverse effects imparted by current therapies. The therapeutic strategies based on mesenchymal stromal cell (MSC) transplantation have become the promising approach for the treatment of autoimmune diseases due to the immunomodulation property of MSCs. MSCs derived from perinatal tissues are collectively known as perinatal MSCs (PMSCs), which can be obtained via painless procedures from donors with lower risk of being contaminated by viruses than those MSCs from adult tissue sources. Therefore, PMSCs may be the ideal cell source for the treatment of autoimmune diseases. This article summarizes recent progress and possible mechanisms of PMSCs in treating autoimmune diseases in animal experiments and clinical studies. This review also presents existing challenges and proposes solutions, which may provide new hints on PMSC transplantation as a therapeutic strategy for the treatment of autoimmune diseases.
\end{abstract}

Keywords: Perinatal tissues, Mesenchymal stromal cell, Umbilical cord, Placental membranes, Amniotic fluid, Immune diseases

\section{Introduction}

Mesenchymal stromal cells (MSCs), a kind of cells with self-renewal and multiple differentiation characteristics, have a broad application prospect in the field of regenerative medicine [1]. A series of MSCs have been isolated from different tissue sources, including the bone marrow, adipose, umbilical cord, umbilical cord blood, placenta, amniotic fluid, hair follicle, and dental pulp tissue [2-7] Among them, the umbilical cord, umbilical cord blood, placenta, and amniotic fluid are the sources that can be collected at the perinatal period, and the MSCs from these tissues are collectively known as

\footnotetext{
*Correspondence: yangchao1207@qq.com; qchen0810@126.com 'Stem Cells and Regenerative Medicine Research Center, Sichuan Stem Cell Bank/Sichuan Neo-life Stem Cell Biotech Inc., 15 Jinquan Road, Chengdu 610036, China

Full list of author information is available at the end of the article
}

perinatal MSCs (PMSCs). Bone marrow-derived MSCs (BMSCs) are the classical adult MSCs and have become the reference to define the biological characteristics of MSCs from various other sources. Previous studies have demonstrated that MSCs from umbilical cord tissues show less capacity in proliferation and differentiation toward adipocyte and osteocyte lineages, but MSCs are less immunogenic with higher immunosuppression activity compared with BMSCs $[8,9]$. Furthermore, PMSCs can be obtained via painless procedures from donors with lower risk of being contaminated by viruses than MSCs from other adult tissue sources $[9,10]$. Therefore, PMSCs are considered as one of the candidate cell sources for clinical applications.

The developing embryo is connected to the placenta by the umbilical cord and immersed in amnion fluid. The amnion fluid is in a sac comprised of the amnion,

\section{$\triangle B M C$}

(C) The Author(s). 2021 Open Access This article is licensed under a Creative Commons Attribution 4.0 International License, which permits use, sharing, adaptation, distribution and reproduction in any medium or format, as long as you give appropriate credit to the original author(s) and the source, provide a link to the Creative Commons licence, and indicate if changes were made. The images or other third party material in this article are included in the article's Creative Commons licence, unless indicated otherwise in a credit line to the material. If material is not included in the article's Creative Commons licence and your intended use is not permitted by statutory regulation or exceeds the permitted use, you will need to obtain permission directly from the copyright holder. To view a copy of this licence, visit http://creativecommons.org/licenses/by/4.0/ The Creative Commons Public Domain Dedication waiver (http://creativecommons.org/publicdomain/zero/1.0/) applies to the data made available in this article, unless otherwise stated in a credit line to the data. 
chorion, etc. [11]. Nowadays, several cell types including MSCs and epithelial cells can be isolated from amnion fluid, and amniotic fluid-derived stem cells (AFSCs) have been considered as a potential candidate for cell transplantation and therapy [12]. Although amniotic fluidderived MSCs (AFMSCs) may have advantages concerning harvesting method and propagation rate [4], MSCs from the umbilical cord (UCMSCs) and placenta (PDMS Cs) are used more widely than AFSCs in reviewed research studies and clinical trials using PMSCs. The umbilical cord blood contains limited MSCs (UCBMSCs). Additionally, cryopreservation of the umbilical cord blood in banks do not need to isolate the MNCs using Ficoll-Hypaque-Plus solution; it only requires removing red cells and excessive nucleated cell-poor plasma through hetastarch and centrifugation. Isolation of UCBMSCs from the umbilical cord blood needs to isolate the MNCs using Ficoll-Hypaque-Plus solution and seed into culture plates with medium formulated for MSCs to select for UCBMSCs. This procedure is not compatible with that for hematopoietic stem cells. It may be possible to isolate hematopoietic stem cells with CD34+ magnetic beads prior to seeding into culture plates for UCBMSCs, but it is not the current standard procedure in umbilical cord blood banks [13-15]. Therefore, isolating UCBMSCs may affect the storage of hematopoietic stem cells in umbilical cord blood banks, which restricts the application of UCBMSCs. In short, the umbilical cord, especially Wharton's jelly compartment, and placenta have become the important sources to isolate MSCs for therapy.

Although UCMSCs are derived from the umbilical cord, a previous study has shown that MSCs from different compartments, including umbilical amnion (AMMS Cs), subamnion (SAMSCs), perivascular (PVMSCs), Wharton's jelly (WJMSCs), and mixed umbilical cord (MCMSCs), have diverse biological properties. WJMSCs show less non-stem cell contaminants, but more stemness characteristics and differentiation potential than PVMSCs, SAMSCs, AMMSCs, and MCMSCs [16]. Meanwhile, our previous study showed that MSCs from the umbilical cord and different membranes of the placenta also exhibited dissimilar biological characteristics. For instance, MSCs derived from decidua parietalis (DPMSCs) are of maternal origin, but MSCs from the umbilical cord, amniotic membrane (AMMSCs), and chorionic plate (CPMSCs) are of fetal origin. Additionally, AMMSCs exhibit better capacity in the secretion of prostaglandin E2 (PGE2) and transforming growth factor $\beta 1$ (TGF- $\beta 1$ ) related to immunomodulation, whereas CPMSCs secrete higher levels of hepatocyte growth factor (HGF) and vascular cell adhesion molecule-1 (VCAM-1), and DPMSCs release higher levels of vascular endothelial growth factor (VEGF) and angiopoietin-1
(ANG-1) [3]. Differences in secretion potentially relate to differences in biological activity, ultimately providing choice of suitable MSCs from the various tissue sources or compartments related to clinical requirements and applications. Figure 1 presents the main human perinatal tissues from which PMSCs can be obtained. The similarities and differences of biological characteristics in MSCs from different perinatal tissues are summarized in Table 1.

As a matter of fact, PMSCs are not just used as seed cells for tissue engineering; they exhibit extraordinary capacity in immunomodulation through the secretion of high levels of paracrine cytokines and direct contact mediated by cell adhesion molecules [17-21]. Therefore, MSCs have been used for many immune diseases such as graft-versushost disease after hematopoietic stem cell transplantation and cytokine storm in critical patients with coronavirus disease 2019 (COVID-19) [22, 23]. Deservedly, MSCs can be also used for the autoimmune diseases, including systemic lupus erythematosus (SLE), lupus nephritis (LN), rheumatoid arthritis (RA), multiple sclerosis (MS), and so forth [24-29]. To date, lots of drugs including antibodies for B lymphocyte, immunosuppressive agents, corticosteroids, and non-steroidal drugs have been used for the treatment of autoimmune diseases [30]. However, many adverse effects such as serious infection, malignant tumorigenesis, and femoral head necrosis limit the clinical application of these drugs [31, 32]. Thus, PMSC transplantation has been considered as a promising strategy for the treatment of various autoimmune diseases. This review mainly summarizes progress and possible mechanisms of MSCs from perinatal tissues to treat autoimmune diseases in animal experiments and clinical studies for the past 15 years and discusses the existing challenges and their possible solutions. The key words for search at "https://pubmed.ncbi.nlm.nih.gov/" are "autoimmune diseases," "perinatal tissues," "stem cell," "mesenchymal stem cell," "mesenchymal stromal cell," "MSCs," "umbilical cord," "umbilical cord blood," "placenta," "decidua parietalis," "amniotic membrane," "chorionic plate," "amniotic fluid," "systemic lupus erythematosus," "lupus nephritis," "rheumatoid arthritis," "multiple sclerosis," "experimental autoimmune encephalomyelitis," "psoriasis," "primary Sjögren's syndrome," "type 1 diabetes," and their combinations. The references were published from 2005 to 2020 , mainly from 2010 to 2020 . The referred articles include original studies, clinical trials, reviews, and metaanalysis. Initially, 151 articles were evaluated for inclusion, and 115 articles were included in the final version.

\section{Pre-clinical applications in autoimmune diseases Systemic lupus erythematosus}

As a typical autoimmune disease, SLE is characterized by overactivation of $\mathrm{B}$ and $\mathrm{T}$ lymphocytes, accompanied 


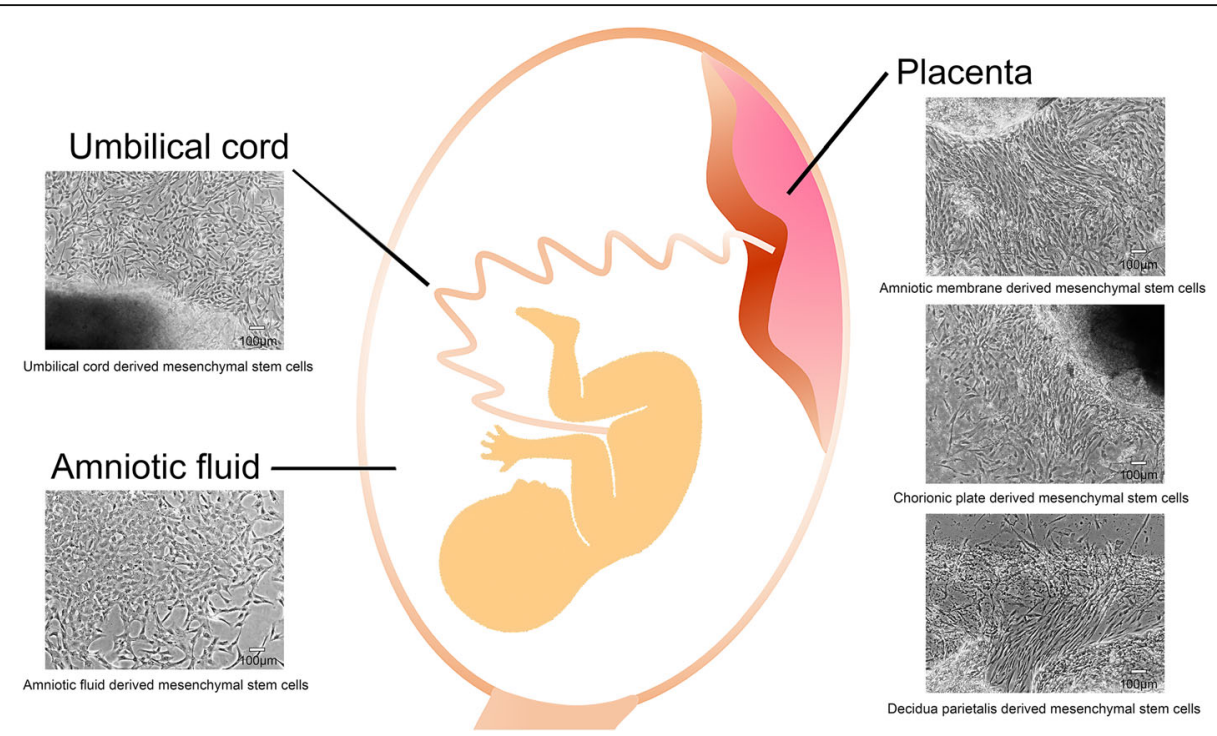

Fig. 1 The main human perinatal tissues to obtain mesenchymal stromal cells (MSCs). Umbilical cord- and placenta-derived MSCs can be acquired via tissue explant adherent cultivation method, while amniotic fluid-derived MSCs can be collected by concentration and cultivation. The MSCs from these tissues present the classic spindle shape and adhere to plastic. Additionally, MSCs can be isolated from different membranes of the placenta or different compartments of the umbilical cord

by secretion of large amounts of inflammatory cytokines and autoantibody, resulting in the damage and dysfunction of multiple organs [33].

Previous studies reported that olfactory 1 /early B cell factor-associated zinc-finger protein (OAZ) was highly expressed in SLE patients, which impairs the function of MSCs to inhibit B cell proliferation and terminal differentiation, leading to increased levels of IgG, IgM, and anti-nuclear antibodies. Silencing of OAZ expression restored the immunosuppressive effect of MSCs on B cells. Therefore, it was speculated that transplantation of normal MSCs might suppress the B cell activity and reduce autoantibody production in SLE patients to alleviate the related symptom [34, 35].

$\mathrm{T}$ lymphocytes $(\mathrm{CD} 3+)$ mainly contain two subsets, CD4+ T helper (Th) cells and CD8+ cytotoxic T (Tc) cells. Previous studies have demonstrated that $\mathrm{T}$ cells from SLE patients have defective mitochondria with mitochondrial hyperpolarization, ATP depletion, and increased apoptosis compare to those from healthy donors $[36,37]$. Chen et al. have also confirmed that SLE patients have excessive mitochondria within $\mathrm{T}$ cells, and these $\mathrm{T}$ cells also have overactivated autophagy and are prone to apoptosis after stimulation with anti-CD3/C28 antibodies. UCMSCs transfer mitochondria to activate $\mathrm{T}$ cells after co-culture for $12 \mathrm{~h}$, which inhibits respiratory mitochondrial accumulation and autophagy activation in $\mathrm{T}$ cells, leading to the rescue of $\mathrm{T}$ cells from apoptosis [38]. Another study has demonstrated that UCMSCs can induce $\mathrm{CD} 4+\mathrm{T}$ cell apoptosis in vitro and in vivo, which also reduces the ratio of Th1 to Th2 cells to further suppress the humoral inflammatory response [39], and PGE2 secreted by UCMSCs participates in this apoptosis-promoting process [40]. These results indicate that UCMSCs inhibit autophagy but promote CD4+ T cell apoptosis to achieve the therapeutic effects. Besides CD4+ T cells, CD8+ T cells also play a crucial role both in the initiation and promotion of autoantigen-specific humoral immunity in SLE patients. A previous study demonstrated that the levels of indoleamine 2, 3dioxygenase (IDO) secreted by allogeneic UCMSCs were enhanced by high levels of interferon- $\gamma$ (IFN- $\gamma$ ), which was mainly released by CD8+ $\mathrm{T}$ cells of SLE patients. The proliferation of $\mathrm{T}$ cell was inhibited in patients merely by this large amount of IDO. Therefore, CD $8+\mathrm{T}$ cell/IFN- $\gamma / \mathrm{IDO}$ axis is critical for mediating the therapeutic effects of allogeneic UCMSCs in SLE patients [41]. However, it is interesting that autologous BMSCs from the patients are defective in IDO secretion in response to IFN- $\gamma$, suggesting autologous BMSCs might not be a suitable therapeutic cell source for SLE [41]. Later, a clinical study proved that higher baseline levels of IFN- $\gamma$ might predict a good response to UCMSCs in SLE patients, indicating baseline levels of IFN- $\gamma$ could be one of the biomarkers to establish the clinical inclusion/ exclusion criteria for UCMSC application in SLE patients [42].

Regulatory $\mathrm{T}$ (Treg) cells are an immunosuppressive subset of CD4+ $\mathrm{T}$ cells and responsible for maintaining immune homeostasis and self-tolerance in healthy 
Table 1 The similarities and differences of biological characteristics in MSCs from different perinatal tissues

\begin{tabular}{|c|c|c|c|}
\hline Perinatal tissues & & Similarities & Differences \\
\hline \multirow[t]{5}{*}{$\begin{array}{l}\text { Umbilical cord and } \\
\text { compartments [16] }\end{array}$} & $\begin{array}{l}\text { Wharton's jelly } \\
\text { (WJMSCs) }\end{array}$ & \multirow{5}{*}{$\begin{array}{l}\text { 1. Adherence to plastic; } \\
\text { 2. Positive for SSEA-3, SSEA-4, } \\
\text { Tra-1-60, and Tra-1-81; } \\
\text { 3. Adipogenic potential and } \\
\text { levels of telomerase activity at } \\
\text { passage } 1 \text {. }\end{array}$} & \multirow{5}{*}{$\begin{array}{l}\text { 1. WJMSCs show significantly greater numbers in primary culture } \\
\text { compared to other MSCs; } \\
\text { 2. WJMSCs show significantly greater proliferation rates at passages 3, } \\
\text { 5, and } 10 \text { compared to other MSCs; } \\
\text { 3. The telomerase levels for WJMSCs were significantly greater than } \\
\text { other MSCs at passage 10; } \\
\text { 4. WJMSCs express significantly greater for CD29, CD44, CD73, HLA- } \\
\text { ABC, CD24, CD108, OCT1, OCT4A, OCT4B, NANOG, and SOX2 com- } \\
\text { pared to other MSCs; } \\
\text { 5. WJMSCs and PVMSCs express significantly greater for CD146 and } \\
\text { CD271 compared to other MSCs; } \\
\text { 6. WJMSCs and PVMSCs express significantly less for fibroblast-related } \\
\text { genes FAP, FSP, CD40, CD49d, and CD140b compared to other MSCs; } \\
\text { 7. WJMSCs exhibit greater osteogenic and chondrogenic } \\
\text { differentiation potential compared to other MSCs. }\end{array}$} \\
\hline & $\begin{array}{l}\text { Amnion } \\
\text { (AMSCs) }\end{array}$ & & \\
\hline & $\begin{array}{l}\text { Subamnion } \\
\text { (SAMSCs) }\end{array}$ & & \\
\hline & $\begin{array}{l}\text { Perivascular } \\
\text { (PVMSCs) }\end{array}$ & & \\
\hline & $\begin{array}{l}\text { Mixed cord } \\
\text { (UCMSCs) }\end{array}$ & & \\
\hline \multirow{4}{*}{$\begin{array}{l}\text { Umbilical cord and } \\
\text { membranes of the } \\
\text { placenta [3] }\end{array}$} & $\begin{array}{l}\text { Umbilical cord } \\
\text { (UCMSCs) }\end{array}$ & \multirow{4}{*}{$\begin{array}{l}\text { 1. Adherence to plastic; } \\
\text { 2. Positive for CD73, CD } 90 \text {, } \\
\text { CD105, SOX2, and SSEA4 } \\
\text { 3. Negative for CD } 45, \text { HLA-DR, } \\
\text { CD34, and CD14; } \\
\text { 4. Adipogenic, osteogenic, and } \\
\text { chondrogenic differentiation } \\
\text { potential. }\end{array}$} & \multirow{4}{*}{$\begin{array}{l}\text { 1. CPMSCs express greater for CD106 compared to other MSCS; } \\
\text { 2. AMMSCs, CPMSCs, and UCMSCs were of fetal origin, and DPMSCs } \\
\text { were of maternal origin; } \\
\text { 3. UCMSCs show shorter population doubling time than other MSCs; } \\
\text { 4. AMMSCs exhibit better capacity in the secretion of PGE2 and TGF- } \\
\beta 1 \text {; } \\
\text { 5. CPMSCs secrete higher level of HGF and VCAM-1; } \\
\text { 6. DPMSCs release higher levels of VEGF and ANG-1. }\end{array}$} \\
\hline & $\begin{array}{l}\text { Amniotic } \\
\text { membrane } \\
\text { (AMMSCs) }\end{array}$ & & \\
\hline & $\begin{array}{l}\text { Chorionic plate } \\
\text { (CPMSCs) }\end{array}$ & & \\
\hline & $\begin{array}{l}\text { Decidua } \\
\text { parietalis } \\
\text { (DPMSCs) }\end{array}$ & & \\
\hline \multirow[t]{2}{*}{$\begin{array}{l}\text { Umbilical cord and } \\
\text { amnion fluid [4] }\end{array}$} & $\begin{array}{l}\text { Wharton's jelly } \\
\text { (WJMSCs) }\end{array}$ & \multirow{2}{*}{$\begin{array}{l}\text { 1. Adherence to plastic; } \\
\text { 2. Growth characteristics at } \\
\text { passage 5; } \\
\text { 3. Positive for the expression of } \\
\text { CD29, CD105, HLA-ABC, and } \\
\text { OCT4; } \\
\text { 4. Negative for CD34 and HLA- } \\
\text { DR; } \\
\text { 5. Myocardial-like cells differenti- } \\
\text { ation capacity in vitro. }\end{array}$} & \multirow[t]{2}{*}{$\begin{array}{l}\text { 1. AFMSCs show greater growth characteristics at passage } 10 \text { than } \\
\text { WJMSCs. }\end{array}$} \\
\hline & $\begin{array}{l}\text { Amnion fluid } \\
\text { (AFMSCS) }\end{array}$ & & \\
\hline \multirow[t]{2}{*}{$\begin{array}{l}\text { Placenta and umbilical } \\
\text { cord blood [7] }\end{array}$} & $\begin{array}{l}\text { Placenta } \\
\text { (PMSCs) }\end{array}$ & \multirow{2}{*}{$\begin{array}{l}\text { 1. Adherence to plastic; } \\
\text { 2. Positive for the expression of } \\
\text { CD44, CD73, CD90, CD105, and } \\
\text { KLF4; } \\
\text { 3. Negative for CD14, CD34, and } \\
\text { CD45; } \\
\text { 4. Growth characteristics; } \\
\text { 5. Adipogenic, osteogenic, and } \\
\text { chondrogenic differentiation } \\
\text { potential; } \\
\text { 6. Immunomodulatory effects. }\end{array}$} & \multirow[t]{2}{*}{$\begin{array}{l}\text { 1. PMSCs are positive for the expression of NANOG; } \\
\text { 2. UCBMSCs are positive for expression of MYC. }\end{array}$} \\
\hline & $\begin{array}{l}\text { Umbilical cord } \\
\text { blood } \\
\text { (UCBMSCs) }\end{array}$ & & \\
\hline
\end{tabular}

individuals [43, 44]. Previous study has demonstrated the reduction and dysfunction of Treg cells in SLE patients [45]. Meanwhile, histocompatibility locus antigenG (HLA-G), also named as human leukocyte antigen-G, has been proved to be involved in the immunosuppressive properties of MSCs [46]. Soluble forms of HLA-G (sHLA-G) have been demonstrated to contribute to the proliferation of Treg cells in vitro. Later another study found that the levels of sHLA-G in serum increased significantly along with the upregulation of Treg cells after allogenic UCMSC transplantation in SLE patients, indicating that UCMSCs may upregulate Treg cells via sHLA-G [47]. Darlan et al. found that TGF- $\beta 1$ released by MSC also promoted the generation of inducible Treg (iTreg) cells in the peripheral blood mononuclear cells (PBMCs) of human SLE patients [48].

In addition to Treg cells, T helper 17 (Th17) cells also play an important role in the pathogenesis of SLE [49]. This process involves the imbalance of Treg and Th17 cells in particular. It is interesting that another study showed that IL-17 production from CD4+ T cells, which was purified from PBMCs, in both healthy donor and SLE patients were upregulated by PGE2 and IL-1 $\beta$ secreted by UCMSCs [50]. These results suggested that the other subpopulations besides CD4+ T cells might suppress the activity of Th17 cells and the secretion of 
IL-17. Furthermore, UCMSCs also significantly upregulate peripheral tolerogenic blood $\mathrm{CD} 1 \mathrm{c}+$ dendritic cells (DCs) and promote CD206 expression and phagocytic activity of macrophages to alleviate SLE [24, 51].

\section{Lupus nephritis}

$\mathrm{LN}$ is a potentially destructive outcome and major risk factor for morbidity and mortality in SLE [52]. LN is characterized by conventional clinical parameters, including proteinuria, high level of anti-dsDNA, and antinuclear antibodies [53]. The overactivation of various immune cells and overproduction of related proteins or antibodies play critical roles in the pathogenesis of LN. UCMSCs and PDMSCs have been reported to exhibit the therapeutic effect to decrease the extent of renal injury and improve the clinical parameters.

Overproduction of monocyte chemoattractant protein1 (MCP-1) and high-mobility group box chromosomal protein 1 (HMGB-1) has been found to act as the important factors for LN [54, 55]. Gu et al. reported that UCMSC transplantation alleviated the severity of proteinuria, downregulated the levels of serum creatinine and anti-dsDNA antibody, and inhibited the expression of MCP-1 and HMGB-1. Additionally, UCMSCs could be found in the kidney of the MRL/lpr mice for at least 11 weeks [56]. Podocyte injury, which is typically involved in nephropathy with proteinuria, contributes to the pathogenic development of LN. UCMSCs not only reduce immunoglobulin $\mathrm{G}$ (IgG) and $\mathrm{C} 3$ deposition in glomeruli and decrease anti-dsDNA antibody levels, but also induce the macrophages exhibiting an antiinflammatory phenotype to prevent podocyte injury [57]. In addition to UCMSCs, PDMSCs can also reduce the severity of proteinuria and the production of antidsDNA antibodies in addition to ameliorating renal pathological changes by inhibiting the expression of inflammatory cytokines, including nuclear factor kappa B (NF-kB), tumor necrosis factor $\alpha$ (TNF- $\alpha$ ), and so on [58]. Furthermore, besides untreated MSCs used for LN, hydroxychloroquine-pretreated UCMSCs have also been researched to obtain better therapeutic effect than that of untreated UCMSCs, suggesting appropriate pretreatment of MSCs before transplantation can promote better clinical outcomes [59].

\section{Rheumatoid arthritis}

RA is a chronic autoimmune joint disease and characterized by invasive synovium inflammation, leading to cartilage and bone destruction and even disability. Although some patients can now benefit from antirheumatic drugs, many still do not receive desired clinical outcomes from current therapies. Therefore, either new therapies need to be developed, or current ones improved urgently [60]. Many studies have reported that
UCMSC and UCBMSC transplantation could be potential therapeutic strategies for the treatment of RA.

UCMSCs benefit RA patients through regulating the ratio/function of immune cells and decreasing inflammatory cytokines in joints and serum. Previous studies demonstrated that UCMSCs inhibit the proliferation and IL-6 secretion of fibroblast-like synoviocytes (FLSs) but promote Treg cell expansion in RA patients by secreting IL-10, IDO, and TGF- $\beta 1$. Further animal experiments determined that UCMSCs downregulated the levels of TNF $\alpha$, IL-6, and MCP-1, and upregulated the levels of IL-10, leading to the relief of the severity of collageninduced arthritis (CIA) [61, 62]. In addition, cadherin-11 (CDH11) is a type II cadherin predominantly expressed by FLSs and is involved in the pathogenesis of RA. UCMSCs could inhibit the expression of CDH11 via IL10 to prevent cartilage erosion [63]. Abnormal activation and differentiation of $\mathrm{T}$ lymphocytes is one of the crucial inducements of inflammation, cartilage, and bone destruction in RA. UCMSCs inhibit the expansion and promote the apoptosis of $\mathrm{T}$ lymphocytes and decrease the ratio of Th17/Treg cells in the spleen and joints of CIA rats. Moreover, UCMSCs also decrease the levels of pro-inflammatory IL-17 but increase the levels of antiinflammatory TGF- $\beta$ in serum to ameliorate symptoms [64]. It is interesting that chemical molecules, such as quercetin, may upregulate the immunomodulatory effect of UCMSCs and improve the outcomes by increasing the functional molecules, including nitric oxide, IDO, and IL-6 via activation Toll-like receptor-3 signaling, suggesting pretreated MSCs may be a potential therapeutic for the treatment of RA in the clinic [65].

Similar to UCMSCs, UCBMSCs have also been reported to significantly downregulate pro-inflammatory cytokines, including TNF- $\alpha$, IL- 1 , and IFN- $\gamma$, but upregulate IL-10. Histologic analysis reveals that UCBMSCs reduce the infiltration of immune cells and hypertrophy of the synovial tissue, ultimately decrease the severity of arthritis induced by Freund's complete adjuvant [66]. Furthermore, macrophages are responsible for the pathogenesis of RA via producing core inflammatory cytokines [67]. Shin et al. found that UCBMSCs could polarize naive macrophages toward an $\mathrm{M} 2$ phenotype via regulating the production of TNF- $\alpha$ and IL-1 $\beta$ [68].

\section{Multiple sclerosis and experimental autoimmune encephalomyelitis}

MS is an autoimmune disorder in the central nervous system and characterized by chronic inflammation and multifocal demyelination [69]. In recent decades, the clinical strategy for the treatment of MS remain relatively disappointing and face many challenges [70]. MSC transplantation is a promising therapeutic strategy for future treatment of MS, and experimental autoimmune 
encephalomyelitis (EAE) is currently the appropriate animal model for MS research.

UCMSC transplantation attenuated the behavioraldeficit scores through ameliorating demyelination and axonal damage, promoting remyelination in the spinal cord of EAE mice via trophic support properties, and modulation of immune cell function [71, 72]. Moreover, UCMSCs exhibit immunoregulation effect to modulate the ratios of Th1/Th2 cells and Th17/Treg cells in the spleen, leading to increased IL-4 and IL10 but decreased IL- 1 and IL- 6 in the spinal cord [72]. Although most of the UCMSCs are cleared away, a fraction of cells can survive up to 3 weeks in the lung and spleen [71]. A similar therapeutic effect is also presented in the primate model of EAE; UCMSCs ameliorate clinical signs of EAE and reduce inflammation and demyelination in the central nervous system via promoting anti-inflammatory immune cells and cytokines while inhibiting pro-inflammatory immune cells and cytokines, and suppressing astrocyte activation in cynomolgus monkeys of EAE [73].

Gene modification and reagent stimulation are used to improve the therapeutic effect of UCMSCs in EAE models. Sphingosine kinase 1 (SPK1) catalyzes sphingosine phosphorylation process to produce sphingosine 1phosphate, which plays a critical role in cell proliferation, migration, and immune regulation [74]. Wang et al. reported that SPK1-transfected UCMSCs presented better therapeutic activity than wildtype UCMSCs in the EAE model, including reducing the severity of neurological deficits, inhibiting myelin oligodendrocyte glycoprotein (MOG)-specific $\mathrm{T}$ cells and NK cells, and promoting Treg cells [75]. Tetramethylpyrazine (TMP) as an alkaloid monomer extracted from traditional Chinese herbs can facilitate the proliferation of neural stem cells and have anti-inflammatory and anti-apoptotic properties. Zhang et al. demonstrated that TMP not only increased cell viability but also reduced intracellular reactive oxygen species (ROS) production via nuclear factor-erythroid 2-related factor-2 (Nrf2)/heme oxygenase 1 (HO-1) signaling. Further experiments determined that TMP-treated UCMSCs also exhibited better effects on the attenuation of inflammation, demyelination, and blood-brain barrier disruption than those of untreated UCMSCs [76]. However, not all of the modification and reagent stimulation of MSCs are beneficial to the amelioration of EAE. Although IFN- $\gamma$, IL- $1 \beta$, and TNF- $\alpha$ pretreatment (called licensing) increase the expression of immune-modulatory molecules and enhance the immunosuppressive potential of UCMSCs, in vitro licensed UCMSCs do not ameliorate EAE. This above study also confirmed that licensing alters the surface marker profile of UCMSCs toward a more immunogenic phenotype, suggesting that a fast rejection is earlier than the immunomodulation effect of licensed UCMSCs, which may cause the failure of treatment [71].

PDMSCs also play a positive role in the treatment of EAE. Firstly, PDMSCs can decrease the levels of IL-17 and increase the production of IL-4 and IL-10 to reduce inflammation partly through tumor necrosis factor $\alpha$ stimulated gene-6 (TSG-6) activation [77, 78]. Secondly, PDMSCs promote the expression of neurotrophic factors such as brain-derived neurotrophic factor, nerve growth factor, and neurotrophin 3 in the brains of EAE rats [79]. Thirdly, PDMSCs can migrate into inflamed tissues and express neural-glial lineage markers while maintaining the anti-inflammatory, axon-preserving, and demyelination-ameliorating properties [80]. Of particular attention is that the route of administration of MSCs influences the therapeutic outcome of EAE. Previous studies demonstrated an improvement in disease symptoms following intravenous, intracerebral, and intraperitoneal injection of MSCs in the EAE mice [71, 73, 77, 78]. Later, Shapira et al. examined the systemic delivery of PDMSCs via intramuscular implantation due to the low risk of pulmonary obstruction through this route. However, intramuscular PDMSC implantation exhibited only marginal effect in inhibiting neuroinflammation and no effect in treating established disease [81]. Additionally, the previous study also revealed that functional peptides and protein co-transplantation could improve the therapeutic effect; for instance, synthetic C16 peptide and ANG-1 increased the engraftment efficacy of PDMSC in the CNS and promoted expression of the neurotropic factors and differentiation of the transplanted PDMSCs [82].

\section{Psoriasis}

Psoriasis is a chronic and systemic disorder with abnormal keratinocyte proliferation and immune cell infiltration in the dermis and epidermis which seriously affect the patients' quality of life [83]. The previous study investigated the possible therapeutic mechanisms and demonstrated that UCMSCs ameliorated the skin inflammation in an imiquimod-induced psoriasis model, and attenuated the production of type I IFN by plasmacytoid DCs [84]. Not only that, another study also found that UCBMSCs treated DCs repressed the activation and differentiation of $\mathrm{CD} 4+\mathrm{T}$ cells which are important for the pathogenesis of psoriasis [85], suggesting that these MSCs not only repress DC function but also alter the immune properties. Furthermore, pro-inflammatory cytokines and chemokines, including IL-6, IL-17, TNF- $\alpha$, chemokine (C-C motif) ligand (CCL) 17, CCL20, and CCL27 were downregulated after treatment $[84,85]$.

Besides UCMSCs and UCBMSCs, AMSCs can also attenuate epidermal acanthosis and neutrophil infiltration of the epidermis in imiquimod-induced psoriasis mice. 
Moreover, AMSCs suppress the expression of CXC chemokine ligand (CXCL) 1 and downregulate IL-17A and IL-22 production from $\gamma \delta$-low T cells. It is interesting that AMSC conditioned medium also inhibits the IL- 8 secretion by human epidermal keratinocytes induced by IFN- $\gamma$ and TNF- $\alpha$ [86].

\section{Primary Sjögren's syndrome}

Primary Sjögren's syndrome is a systemic autoimmune disease characterized by aberrant activation of immune responses and lymphocytic infiltration of the salivary and lacrimal glands, leading to xerostomia and xerophthalmia [87, 88]. Recent studies have reported that UCMSCs alleviate the related symptoms via mediating the functions of T17 cells, Treg cells, $\mathrm{T}$ follicular helper (Tfh) cells, and macrophages.

The imbalance of Treg/Th17 cells has been proven to be involved in the development of autoimmune diseases [89]. Alunno et al. found that IFN- $\gamma$-pretreated microencapsulated-UCMSCs suppress $\mathrm{T}$ cell proliferation and restore the Treg/Th17 ratio in PBMCs from primary Sjögren's syndrome patients [90]. And not only that, UCMSCs also downregulate the production of proinflammatory cytokines including IFN- $\gamma$, IL-6, and TNF $\alpha$ but upregulate the production of IL-10, leading to the reduction of inflammatory infiltrates and the increase of salivary flow [91]. Tfh cells are a specialized CD4+ T cell subset, which are essential for B cell maturation [92]. The frequency of circulating Tfh cells correlates with serum autoantibody levels in patients [93]. UCMSCs suppress the differentiation and proliferation of Tfh cells via the secretion of IDO, whereas the production of IDO by UCMSCs is also promoted by naive CD4+ T cells under Tfh cell-polarizing conditions with cell-to-cell contact but not in a trans-well system [88]. Macrophages are important cells for immune system, and the accumulation of macrophages in lacrimal glands and salivary glands has been found in primary Sjögren's syndrome patients [94]. Lu et al. demonstrated that UCMSCs activated AKT pathway in macrophages and skewed macrophages into an M2 phenotype, resulting in the downregulation of pro-inflammatory M1 macrophage and the upregulation of anti-inflammatory M2 macrophage, and alleviation of chronic inflammation in lacrimal glands [95].

\section{Type 1 diabetes}

Type 1 diabetes (T1D) is a chronic autoimmune disease and characterized by pancreatic $\beta$ cell damage, insulin deficiency, and hyperglycemia [96]. Current therapeutic strategies focus on intensifying insulin and preserving $\beta$ cell mass, but different to maintain normal glycemic levels and transient efficacy, respectively [28]. Although T1D remains a huge therapeutic challenge because of the wide gaps in our understanding of this disease, $\mathrm{T}$ cell-mediated destruction of pancreatic $\beta$ cells is one mode of the pathogenesis. MSC transplantation has been reported to treat T1D by the immunomodulatory property of MSCs.

Although human AFSCs have not been used in T1D clinical trials, non-genetically engineered AFSCs have been reported to protect $\beta$ cell from damage and promote $\beta$ cell regeneration in streptozotocin-induced diabetic mice via activation of the insulin receptor/PI3K/ Akt signaling pathway and upregulation of vascular endothelial growth factor-A (VEGF-A) expression [97].

MSCs can differentiate into insulin-producing cells and have given rise to a new approach to replace the damaged pancreatic $\beta$ cells. Previous studies demonstrated that human AMMSCs could differentiate into insulin-producing cells after cultivation in induction medium or knocking down neuronal restrictive silencing factor (NRSF) and Sonic hedgehog (SHH) via PEI@$\mathrm{Fe} 3 \mathrm{O} 4$ nanoparticles. The insulin-producing cells can release insulin in a glucose-responsive manner and normalize hyperglycemia for a long period without immunosuppressive agents $[98,99]$. In addition to AMSCs, human AFSCs can also be induced to differentiate into insulin-producing cells; the induced AFSCs can secret insulin in response to glucose stimulation just like intrinsic pancreatic $\beta$ cells [100].

\section{Clinical trials in autoimmune diseases}

Systemic lupus erythematosus

Safety is the primary consideration in clinical trial of allogeneic UCMSC transplantation for SLE. Many longterm follow-up clinical studies provide evidences that the incidences of adverse events, concerning renal function, liver function, electrocardiogram, infections, malignancies, and so forth, are acceptable, suggesting that allogeneic UCMSC transplantation exhibits a good safety profile in SLE patients [101-103]. A clinical study for 12 months demonstrated that after UCMSC transplantation in active SLE patients, the percentage of peripheral Treg cells increased in the initial 3 months, while the proportion of Th17 cells decreased in the last 9 months. This study also showed that UCMSCs could upregulate the proportion of Treg cells and downregulate the percentage of Th17 cells, but could not influence the production of interleukin (IL)-17A [104]. In addition, UCMSC transplantation elicits a satisfactory clinical response in SLE patients, but repeated infusion for every 6 months is necessary to avoid disease relapse for some patients [105].

\section{Lupus nephritis}

Clinical study showed that multiple assessment indicators, including renal activity, renal function, glomerular 
filtration rate, and total disease activity, were ameliorated after a single intravenous infusion of UCMSCs $\left(1 \times 10^{6}\right.$ cells per kilogram), and this amelioration lasted for 12 months without transplantation-related adverse events, suggesting that allogeneic UCMSC transplantation is safe and efficacious for active and refractory LN patients [106]. However, another clinical study demonstrated that compared with the UCMSC transplantation $\left(2 \times 10^{8}\right.$ cells per patient) group, the placebo group also achieved a similar complete remission proportion of patients [25]. Some researchers proposed that the intravenous infusion approach made the UCMSCs contact patient's immune cells directly, which hampered the immunomodulatory function [107].

\section{Rheumatoid arthritis}

Clinical trials demonstrate that there is no serious adverse effect associated with UCMSC transplantation at the dose of $2 \sim 4 \times 10^{7}$ or UCBMSC transplantation at the dose of $2.5 \sim 10 \times 10^{7}[26,108,109]$. Additionally, UCMSCs or UCBMSCs decrease the serum levels of TNF- $\alpha$ and IL- 6 and increase the percentage of Treg cells in the peripheral blood, according to the results from in vitro and animal RA models [109]. All the clinical trials demonstrate that UCMSC or UCBMSC transplantation induces a significant remission of clinical symptoms of RA, indicating that they are safe and effective approaches for the treatment of RA $[26,108,109]$.

\section{Multiple sclerosis}

A phase $1 \mathrm{~b}$ clinical study of MS demonstrated that PDMSC transplantation at the dose of $1.5 \sim 6 \times 10^{8}$ cells were safe and well tolerated in relapsing-remitting multiple sclerosis and secondary progressive multiple sclerosis patients via intravenous infusion [27].

\section{Psoriasis}

Chen et al. reported two clinical cases of patients who had suffered psoriasis vulgaris more than 10 years and then treated by UCMSCs. UCMSC transplantation significantly reduced the severity and development of psoriasis at least for 4 years [110].

\section{Type 1 diabetes}

$\mathrm{Hu}$ et al. reported that both the HbA1c and C peptide in TID patients with UCMSC transplantation were significantly better than those in the TID patients treated with saline for 21 months, suggesting that UCMSC transplantation is expected to be an ideal therapeutic strategy for T1D [111]. Another clinical study establishes cotransplantation of allogenic UCMSCs with autologous bone marrow mononuclear cells (BMMNCs) without immunotherapy. C-peptide area under the curve and insulin area under the curve are increased, whereas
HbA1c, fasting glycemia, and daily insulin requirements decreased after co-transplantation [28]. These results reveal that transplantation of UCMSC alone or with autologous BMMNCs is safe and promotes the improvement of metabolic measures in T1D patients.

The pre-clinical results and clinical outcomes for each autoimmune disease with respect to PMSC types are summarized in Table 2.

\section{Present progress and challenges of the future}

The therapeutic strategies based on MSC transplantation have become the promising approaches for the treatment of the diseases without satisfactory clinical outcomes provided by current therapies. As mentioned above, PMSCs have been used and received considerable attention for the treatment of various autoimmune diseases without significant adverse effects. The main mechanisms contain mediating the ratio of inflammatory cells to anti-inflammatory cells, inhibiting the levels of inflammatory factors, and promoting anti-inflammatory factors. However, there are also several key points that should be considered for the clinical application in the future.

Firstly, potency evaluation and screening criteria should be established. For instance, MSCs derived from the same type of tissue source have been used for the same disease; however, the results from one clinical trial showed that the patients developed positive clinical outcomes while those from another clinical trial indicated that MSC transplantation did not exhibit desired therapeutic effects $[25,106]$. In such case, the difference of the effects might be caused by the potency of MSCs due to the difference in donors or culture system, including medium components, culture environment, technological standard, etc. Therefore, the challenge is how to establish an evaluation system which can predict the efficacy of MSCs after clinical transplantation. In addition to sterility, safety, activity, uniformity, purity, and stability, the released levels of cytokines (IDO, PGE2, TSG-6, IL-4, IL-6, IL-10, VEGF, HGF, ANG-1, fibroblast growth factor 2, placental growth factor, matrix metalloproteinases, CXCLs, CCLs, etc.) and the expression of surface molecules (CD106, CD54, HLA-G, programmed cell death ligand 1, etc.), which related to immunomodulation and regeneration, should be considered [112-114]. Furthermore, inhibition rate of peripheral blood mononuclear cells quantity and levels of inflammatory factors (TNF- $\alpha$, IFN- $\gamma$, etc.) after co-culture with MSCs in vitro should also be included into the potency evaluation system [48]. Certainly, the animal models of indication should be used to prove the utility of the MSC potency evaluation system. The screening criteria should also contain the inclusion criteria of the donors. The previous study demonstrated that MSCs from the same type 
Table 2 The pre-clinical results and clinical outcomes for each autoimmune disease with respect to PMSC types

\begin{tabular}{|c|c|c|c|}
\hline $\begin{array}{l}\text { Type of } \\
\text { autoimunne } \\
\text { diseases }\end{array}$ & $\begin{array}{l}\text { Type of } \\
\text { PMSCs }\end{array}$ & Pre-clinical results & References \\
\hline SLE & UCMSCS & $\begin{array}{l}\text { Inhibiting B cell activity and autophagy activation in T cells; inducing CD4+ T cell apoptosis; } \\
\text { upregulating the ratio of Th2/Th1; promoting generation of Treg cells, CD1c+DCs, and CD206+ } \\
\text { M2 macrophages }\end{array}$ & $\begin{array}{l}{[24,34,38,39,} \\
47,48,51]\end{array}$ \\
\hline \multirow[t]{2}{*}{ LN } & UCMSCS & $\begin{array}{l}\text { Downregulating the levels of proteinuria, serum creatinine, anti-dsDNA antibody, lgG, and C3 de- } \\
\text { position; inducing macrophages to M2 phenotype }\end{array}$ & {$[56,57]$} \\
\hline & PDMSCs & $\begin{array}{l}\text { Reducing the severity of proteinuria, production of anti-dsDNA antibodies; inhibiting the expres- } \\
\text { sion of inflammatory cytokines NF-KB, TNF-a, etc. }\end{array}$ & [58] \\
\hline \multirow[t]{2}{*}{ RA } & UCMSCs & $\begin{array}{l}\text { Decreasing the ratio of Th17/Treg cells; inhibiting the expression of CDH11; downregulating the } \\
\text { levels of TNFa, IL-6, MCP-1, and IL-17, and upregulating the levels of IL-10 and TGF- } \beta\end{array}$ & [62-64] \\
\hline & UCBMSCs & $\begin{array}{l}\text { Downregulating TNF-a, IL-1, and IFN- } \gamma \text {, but upregulating IL-10; reducing the infiltration of im- } \\
\text { mune cells and hypertrophy of the synovial tissue }\end{array}$ & {$[66,68]$} \\
\hline \multirow[t]{2}{*}{ EAE } & UCMSCS & $\begin{array}{l}\text { Ameliorating demyelination, axonal damage, and promoting remyelination in the spinal cord; } \\
\text { modulating the ratio of Th1/Th2 cells and Th17/Treg cells in the spleen; increasing IL-4 and IL-10 } \\
\text { but decreasing IL-1 and IL-6 in the spinal cord }\end{array}$ & {$[71-73]$} \\
\hline & PDMSCs & $\begin{array}{l}\text { Decreasing infiltrating inflammatory cells, preserving axons, and ameliorating demyelination; } \\
\text { decreasing the levels of COX-2, NF-kB, TNF- } \alpha \text {, IFN- } \gamma \text {, and IL-2, and increasing production of IL-4 } \\
\text { and TGF- } \beta\end{array}$ & {$[77,78,80]$} \\
\hline \multirow[t]{3}{*}{ Psoriasis } & UCMSCS & Ameliorate the skin inflammation; attenuating plasmacytoid DCs to produce type I IFN & [84] \\
\hline & UCBMSCs & Downregulating IL-6, IL-17, TNF-a, CCL17, CCL20, and CCL27 & [85] \\
\hline & AMSCs & Decreasing both IL-17A and IL-22 production by cutaneous $\gamma \delta$-low T cells & [86] \\
\hline $\begin{array}{l}\text { Primary Sjögren's } \\
\text { syndrome }\end{array}$ & UCMSCs & $\begin{array}{l}\text { Suppressing the T cell proliferation and restoring the Treg/Th17 ratio of PBMCs; downregulating } \\
\text { the production of IFN- } \mathrm{y} \text {, IL-6, and TNFa but upregulating production of IL-10; suppressing the dif- } \\
\text { ferentiation and proliferation of Tfh cells; inducing macrophages into an M2 phenotype }\end{array}$ & {$[88,90,91,95]$} \\
\hline T1D & AFSCS & Preserving and promoting endogenous $\beta$ cell functionality and proliferation & [97] \\
\hline $\begin{array}{l}\text { Type of } \\
\text { autoimunne } \\
\text { diseases }\end{array}$ & $\begin{array}{l}\text { Type of } \\
\text { PMSCs }\end{array}$ & Clinical outcomes & References \\
\hline SLE & UCMSCS & $\begin{array}{l}\text { Exhibiting a good safety profile in SLE patients; upregulating the ratio of Treg/Th17; } 32.5 \% \\
\text { patients achieved major clinical response and } 27.5 \% \text { patients achieved partial clinical response } \\
\text { during } 12 \text { months of follow-up. } 12.5 \% \text { and } 16.7 \% \text { patients experienced disease relapse at } 9 \\
\text { months and } 12 \text { months }\end{array}$ & {$[104,105]$} \\
\hline LN & UCMSCS & $\begin{array}{l}\text { Exhibiting a good safety profile in LN patients; ameliorating renal activity, renal function, } \\
\text { glomerular filtration rate, and total disease activity }\end{array}$ & {$[25,106,107]$} \\
\hline \multirow[t]{2}{*}{ RA } & UCMSCS & $\begin{array}{l}\text { Exhibiting a good safety profile in RA patients; decreasing health index and joint function index } \\
\text { of } 1 \text { year and } 3 \text { years after treatment; decreasing the serum levels of TNF-a and IL-6; increasing } \\
\text { the percentage of Treg cells in peripheral blood }\end{array}$ & {$[26,109]$} \\
\hline & UCBMSCs & $\begin{array}{l}\text { Exhibiting a good safety profile in RA patients; reducing levels of IL-1 } \beta, I L-6, I L-8 \text {, and TNF-a; in- } \\
\text { creasing the percentage of Treg cells in peripheral blood; reducing the mean 28-joint disease ac- } \\
\text { tivity score at week } 4\end{array}$ & [108] \\
\hline MS & PDMSCs & Exhibiting a good safety profile in MS patients; decreasing Expanded Disability Status Scale scores & [27] \\
\hline Psoriasis & UCMSCS & Reducing the severity and development of psoriasis at least 4 years & [110] \\
\hline T1D & UCMSCs & $\begin{array}{l}\text { Increasing levels of C peptide and decreasing HbA1c, fasting glycemia, and daily insulin } \\
\text { requirements }\end{array}$ & {$[28,111]$} \\
\hline
\end{tabular}

of tissue source (umbilical cord) but not the same donor exhibited huge differences in the expression profile of immunomodulatory molecules (IOD-1, TSG-6, TGF- $\beta 1$, etc.), which is closely related to the immune-modulatory function of MSCs [71]. Thus, the selection of the donors is critical, and the potency evaluation system should also be used to screen the donors.
Secondly, the route of injection and the selection of the dose should be considered seriously. Generally, intravenous injection is a convenient and common route for most of the autoimmune disease [26, 27, 102, 108, $111]$, but it also comes with the risk of adverse events such as pulmonary embolism [115]. Despite being used for the treatment of the EAE animal model in a previous 
study [77], intraperitoneal infusion has been rarely used for cell delivery for fear of lowering the efficiency. Furthermore, autoimmune diseases are characterized by increased reactivity of the immune system toward selfantigens, resulting in damage or dysfunction of tissues, but different autoimmune diseases usually affect different organs. For instance, LN is characterized by nephritis, RA is characterized by cartilage and bone destruction, and MS is characterized by central nervous system inflammation and multifocal demyelination. Thus, different autoimmune diseases may need different routes of injection, and local injection is also recommended for some autoimmune diseases, for example, intracerebral injection for MS or EAE [78]. For dose selection of MSCs, the climbing dose needs to be designed, which helps to determine the dose-effect relationship, dose-limiting toxicity, and maximum tolerated dose [108]. Additionally, the dose designs are different in previous clinical studies and generally fall into two categories: one is designed according to body weight (for instance $1 \times 10^{6} / \mathrm{kg}$ ) [102], and the other is constant dose per time point or single dose not based on body weight $[26,109]$.

Finally, as mentioned above, gene modification, reagent stimulation (such as chemical reagents and factors), and microenvironment alteration (such as hypoxia induction) should be considered to improve the immunomodulation capacities of MSCs for the treatment of autoimmune diseases [59, 75, 76, 90]. Nowadays, MSCs obtained from traditional and routine culture system face the bottleneck of limited potency although an evaluation system can screen the relatively better cell sources. These strategies above may further improve the therapeutic potential of screened MSCs. Generally speaking, gene modification has the advantages of forced and targeted expression, but will also face stronger regulatory rules for clinical trials whereas factor stimulation or hypoxia induction is more likely to be accepted currently. In the future, just like chimeric antigen receptor $\mathrm{T}$ cells (CAR-T), genetically engineered MSCs may be a trend for therapeutic application. Meanwhile, it is worth considering that some stimulation and alteration may enhance immune-modulatory function of MSCs, but they also may alter the expression profile of MSCs toward a more immunogenic phenotype or other changes in biological characteristics, resulting in the failure of treatment.

\section{Conclusion}

The autoimmune diseases are chronic and systemic disorders and characterized by overactivation of immune cells and chronic inflammation, leading to the damage and dysfunction of multiple organs. However, current therapies for these diseases are based on immunosuppressive agents, corticosteroids, and non-steroidal drugs, which cause many adverse effects. PMSCs exhibit

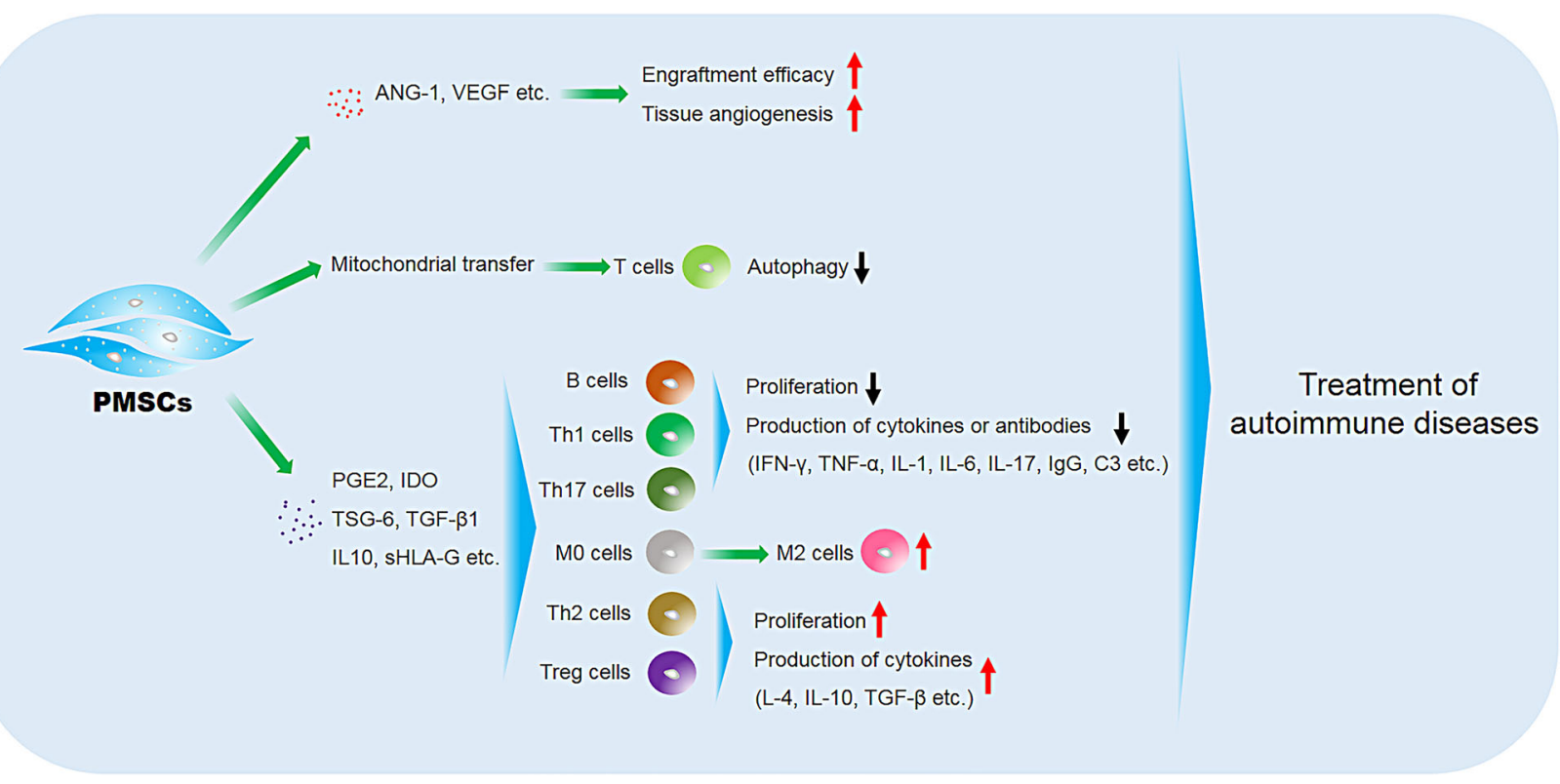

Fig. 2 The main mechanisms of PMSCs for the treatment of autoimmune diseases. PMSCs can suppress the function of B and T cells and decrease the proportion of Th1/Th2, Th17/Treg, and M1/M2 via secreting IDO, PGE2, TSG-6, TGF- $\beta 1$, IL10, sHLA-G, etc. Furthermore, PMSCs can downregulate the levels of inflammatory cytokines as IFN- $\gamma$, TNF- $a, I L-1, I L-6, I L-17$, and the like, but upregulate the levels of IL-4, IL-10, and TGF- $\beta$ in the serum or target tissues after transplantation. Moreover, PMSCs can secrete various growth factors such as VEGF and ANG-1 to enhance the therapeutic effects 
extraordinary capacity in immunomodulation through paracrine route or direct contact, thus can be the candidate for the treatment of autoimmune diseases. As main mechanisms, PMSCs can inhibit the function of $\mathrm{B}$ and $\mathrm{T}$ cells, decrease the ratios of Th1/Th2, Th17/Treg, and M1/ M2 via secreting IDO, PGE2, TSG-6, TGF- $\beta 1$, IL10, sHLA-G, etc. Additionally, PMSCs can downregulate the levels of inflammatory cytokines such as IFN- $\gamma$, TNF- $\alpha$, IL-1, IL-6, IL-17, and the like, but upregulate the levels of IL-4, IL-10, and TGF- $\beta$ in the serum or target tissues after transplantation. Moreover, PMSCs can secrete various growth factors to enhance the therapeutic effects-besides immunomodulation; for example, VEGF or ANG-1 enhances the engraftment efficacy and angiogenesis (Fig. 2). The current clinical trials of PMSCs for the treatment of autoimmune diseases indicate that PMSC transplantation exhibits a good safety profile in autoimmune disease patients. Finally, in order to ensure the efficacy, potency evaluation of PMSCs, the route of injection, and dose selection should be thought over. Furthermore, the methods such as gene modification, reagent stimulation, and microenvironment alteration for improving the therapeutic potential should also be considered.

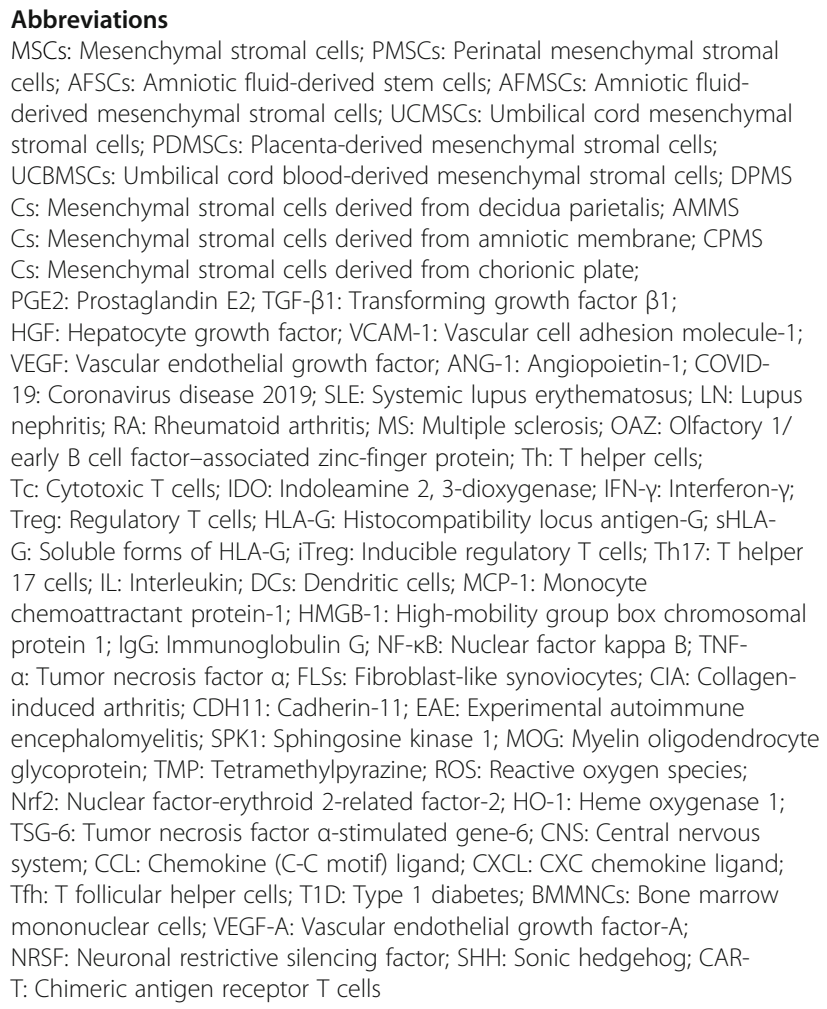
cells; AFSCs: Amniotic fluid-derived stem cells; AFMSCs: Amniotic fluidderived mesenchymal stromal cells; UCMSCs: Umbilical cord mesenchymal stromal cells; PDMSCs: Placenta-derived mesenchymal stromal cells; UCBMSCs: Umbilical cord blood-derived mesenchymal stromal cells; DPMS Cs: Mesenchymal stromal cells derived from decidua parietalis; AMMS Cs: Mesenchymal stromal cells derived from amniotic membrane; CPMS Cs: Mesenchymal stromal cells derived from chorionic plate; PGE2: Prostaglandin E2; TGF- $\beta 1$ : Transforming growth factor $\beta 1$; HGF: Hepatocyte growth factor; VCAM-1: Vascular cell adhesion molecule-1; VEGF: Vascular endothelial growth factor; ANG-1: Angiopoietin-1; COVID19: Coronavirus disease 2019; SLE: Systemic lupus erythematosus; LN: Lupus nephritis; RA: Rheumatoid arthritis; MS: Multiple sclerosis; OAZ: Olfactory 1/ early B cell factor-associated zinc-finger protein; Th: T helper cells; Tc: Cytotoxic T cells; IDO: Indoleamine 2, 3-dioxygenase; IFN- $\gamma$ : Interferon- $\gamma$; Treg: Regulatory T cells; HLA-G: Histocompatibility locus antigen-G; sHLAG: Soluble forms of HLA-G; iTreg: Inducible regulatory T cells; Th17: T helper 17 cells; IL: Interleukin; DCs: Dendritic cells; MCP-1: Monocyte chemoattractant protein-1; HMGB-1: High-mobility group box chromosomal protein 1; IgG: Immunoglobulin G; NF-kB: Nuclear factor kappa B; TNFa: Tumor necrosis factor a; FLSs: Fibroblast-like synoviocytes; CIA: Collageninduced arthritis; CDH11: Cadherin-11; EAE: Experimental autoimmune encephalomyelitis; SPK1: Sphingosine kinase 1; MOG: Myelin oligodendrocyte glycoprotein; TMP: Tetramethylpyrazine; ROS: Reactive oxygen species; Nrf2: Nuclear factor-erythroid 2-related factor-2; HO-1: Heme oxygenase 1; TSG-6: Tumor necrosis factor a-stimulated gene-6; CNS: Central nervous system; CCL: Chemokine (C-C motif) ligand; CXCL: CXC chemokine ligand; Tfh: T follicular helper cells; T1D: Type 1 diabetes; BMMNCs: Bone marrow mononuclear cells; VEGF-A: Vascular endothelial growth factor-A; NRSF: Neuronal restrictive silencing factor; $\mathrm{SHH}$ : Sonic hedgehog; CAR$\mathrm{T}$ : Chimeric antigen receptor $\mathrm{T}$ cells

\section{Acknowledgements}

Not applicable.

\section{Authors' contributions}

Conceptualization, C.Y. and Q.C.; writing —original draft preparation, C.Y.; writing - review and editing, C.Y., M.J.W., M.Y., Y.C., and M.W.L. All authors have read and agreed to the published version of the manuscript.

\section{Funding}

This work was supported by the Project of Health Commission of Sichuan Province (19PJ146).

\section{Availability of data and materials \\ Not applicable.}

Ethics approval and consent to participate

Not applicable.

\section{Consent for publication}

Not applicable.

\section{Competing interests}

The authors declare that they have no competing of interests.

\section{Author details}

${ }^{1}$ Stem Cells and Regenerative Medicine Research Center, Sichuan Stem Cell Bank/Sichuan Neo-life Stem Cell Biotech Inc., 15 Jinquan Road, Chengdu 610036, China. ${ }^{2}$ Center for Stem Cell Research \& Application, Institute of Blood Transfusion, Chinese Academy of Medical Sciences and Peking Union Medical College, Chengdu, China.

Received: 2 November 2020 Accepted: 11 January 2021

Published online: 04 February 2021

\section{References}

1. Han Y, Li X, Zhang Y, Han Y, Chang F, Ding J. Mesenchymal stem cells for regenerative medicine. Cells. 2019;8(8). https://doi.org/10.3390/cells8080886.

2. Jin HJ, Bae YK, Kim M, Kwon S-J, Jeon HB, Choi SJ, Kim SW, Yang YS, Oh W, Chang JW. Comparative analysis of human mesenchymal stem cells from bone marrow, adipose tissue, and umbilical cord blood as sources of cell therapy. Int J Mol Sci. 2013;14(9):17986-8001. https://doi.org/10.3390/ ijms140917986.

3. Wu M, Zhang R, Zou Q, Chen Y, Zhou M, Li X, Ran R, Chen Q. Comparison of the biological characteristics of mesenchymal stem cells derived from the human placenta and umbilical cord. Sci Rep. 2018;8(1):5014. https://doi.org/ 10.1038/s41598-018-23396-1.

4. Bai J, Hu Y, Wang Y-R, Liu L-F, Chen J, Su S-P, Wang Y. Comparison of human amniotic fluid-derived and umbilical cord Wharton's jelly-derived mesenchymal stromal cells: characterization and myocardial differentiation capacity. J Geriatr Cardiol. 2012;9(2):166-71. https://doi.org/10.3724/SP.J. 1263.2011.12091.

5. Hoogduijn MJ, Gorjup E, Genever PG. Comparative characterization of hair follicle dermal stem cells and bone marrow mesenchymal stem cells. Stem Cells Dev. 2006;15(1):49-60.

6. Yang C, Chen Y, Zhong L, You M, Yan Z, Luo M, Zhang B, Yang B, Chen Q. Homogeneity and heterogeneity of biological characteristics in mesenchymal stem cells from human umbilical cords and exfoliated deciduous teeth. Biochem Cell Biol. 2020;98(3):415-25. https://doi.org/10. $1139 /$ bcb-2019-0253.

7. Heo JS, Choi Y, Kim H-S, Kim HO. Comparison of molecular profiles of human mesenchymal stem cells derived from bone marrow, umbilical cord blood, placenta and adipose tissue. Int J Mol Med. 2016;37(1):115-25. https://doi.org/10.3892/ijmm.2015.2413.

8. Bárcia RN, Santos JM, Filipe M, Teixeira M, Martins JP, Almeida J, Água-Doce A, Almeida SCP, Varela A, Pohl S, Dittmar KEJ, Calado S, Simões SI, Gaspar MM, Cruz MEM, Lindenmaier W, Graça L, Cruz H, Cruz PE. What makes umbilical cord tissue-derived mesenchymal stromal cells superior immunomodulators when compared to bone marrow derived mesenchymal stromal cells? Stem Cells Int. 2015;2015:583984. https://doi. org/10.1155/2015/583984.

9. LV F, Lu M, Cheung KMC, Leung VYL, Zhou G. Intrinsic properties of mesemchymal stem cells from human bone marrow, umbilical cord and umbilical cord blood comparing the different sources of MSC. Curr Stem Cell Res Ther. 2012;7(6):389-99.

10. Gong W, Han Z, Zhao H, Wang Y, Wang J, Zhong J, Wang B, Wang S, Wang $Y$, Sun L, Han Z. Banking human umbilical cord-derived mesenchymal stromal cells for clinical use. Cell Transplant. 2012;21(1):207-16. https://doi. org/10.3727/096368911X586756. 
11. Loukogeorgakis SP, De Coppi P. Stem cells from amniotic fluid--potential for regenerative medicine. Best Pract Res Clin Obstet Gynaecol. 2016;31:45-57. https://doi.org/10.1016/j.bpobgyn.2015.08.009.

12. Dziadosz M, Basch RS, Young BK. Human amniotic fluid: a source of stem cells for possible therapeutic use. Am J Obstet Gynecol. 2016;214(3):321-7. https://doi.org/10.1016/.ajog.2015.12.061.

13. Wu JY, Liao C, Xu ZP, Chen JS, Gu SL, Huang YN, Li Y, Tang XW, Yang X, Tang PH, Tsang KS. Banking and transplantation of umbilical cord blood in Guangzhou, China. Cytotherapy. 2006;8(5):488-97.

14. M-Reboredo N, Díaz A, Castro A, Villaescusa RG. Collection, processing and cryopreservation of umbilical cord blood for unrelated transplantation. Bone Marrow Transplant. 2000;26(12):1263-70.

15. Kern S, Eichler H, Stoeve J, Klüter H, Bieback K. Comparative analysis of mesenchymal stem cells from bone marrow, umbilical cord blood, or adipose tissue. Stem cells (Dayton, Ohio). 2006;24(5):1294-301.

16. Subramanian A, Fong CY, Biswas A, Bongso A. Comparative characterization of cells from the various compartments of the human umbilical cord shows that the Wharton's jelly compartment provides the best source of clinically utilizable mesenchymal stem cells. PLoS One. 2015;10(6):e0127992. https:// doi.org/10.1371/journal.pone.0127992.

17. Luz-Crawford P, Ipseiz N, Espinosa-Carrasco G, Caicedo A, Tejedor G, Toupet K, Loriau J, Scholtysek C, Stoll C, Khoury M, Noël D, Jorgensen C, Krönke G, Djouad F. PPARß/ $\delta$ directs the therapeutic potential of mesenchymal stem cells in arthritis. Ann Rheum Dis. 2016;75(12):2166-74. https://doi.org/10. 1136/annrheumdis-2015-208696.

18. Abumaree MH, Abomaray FM, Alshabibi MA, AlAskar AS, Kalionis B. Immunomodulatory properties of human placental mesenchymal stem/ stromal cells. Placenta. 2017;59:87-95. https://doi.org/10.1016/j.placenta. 2017.04.003.

19. Marino L, Castaldi MA, Rosamilio R, Ragni E, Vitolo R, Fulgione C, Castaldi SG, Serio B, Bianco R, Guida M, Selleri C. Mesenchymal stem cells from the Wharton's jelly of the human umbilical cord: biological properties and therapeutic potential. Int J Stem Cells. 2019;12(2):218-26. https://doi.org/10. 15283/ijsc18034

20. Harrell CR, Gazdic M, Fellabaum C, Jovicic N, Djonov V, Arsenijevic N, Volarevic $V$. Therapeutic potential of amniotic fluid derived mesenchymal stem cells based on their differentiation capacity and immunomodulatory properties. Curr Stem Cell Res Ther. 2019;14(4):327-36. https://doi.org/10. 2174/1574888X14666190222201749

21. Corsello T, Amico G, Corrao S, Anzalone R, Timoneri F, Lo lacono M, Russo E, Spatola GF, Uzzo ML, Giuffrè M, Caprnda M, Kubatka P, Kruzliak P, Conaldi $P G$, La Rocca G. Wharton's jelly mesenchymal stromal cells from human umbilical cord: a close-up on immunomodulatory molecules featured in situ and in vitro. Stem Cell Rev Rep. 2019;15(6):900-18. https://doi.org/10.1007/ s12015-019-09907-1.

22. Zhao $K$, Lou R, Huang F, Peng $Y$, Jiang Z, Huang $K$, Wu X, Zhang Y, Fan Z, Zhou H, Liu C, Xiao Y, Sun J, Li Y, Xiang P, Liu Q. Immunomodulation effects of mesenchymal stromal cells on acute graft-versus-host disease after hematopoietic stem cell transplantation. Biol Blood Marrow Transplant. 2015;21(1):97-104. https://doi.org/10.1016/j.bbmt.2014.09.030.

23. Shu L, Niu C, Li R, Huang T, Wang Y, Huang M, Ji N, Zheng Y, Chen $X$, Shi L, Wu M, Deng K, Wei J, Wang X, Cao Y, Yan J, Feng G. Treatment of severe COVID-19 with human umbilical cord mesenchymal stem cells. Stem Cell Res Ther. 2020;11(1):361. https://doi.org/10.1186/s13287-020-01875-5.

24. Yuan X, Qin X, Wang D, Zhang Z, Tang X, Gao X, Chen W, Sun L. Mesenchymal stem cell therapy induces FLT3L and CD1C dendritic cells in systemic lupus erythematosus patients. Nat Commun. 2019;10(1):2498. https://doi.org/10.1038/s41467-019-10491-8.

25. Deng D, Zhang P, Guo Y, Lim TO. A randomised double-blind, placebocontrolled trial of allogeneic umbilical cord-derived mesenchymal stem cell for lupus nephritis. Ann Rheum Dis. 2017;76(8):1436-9. https://doi.org/10. 1136/annrheumdis-2017-211073.

26. Wang L, Huang S, Li S, Li M, Shi J, Bai W, Wang Q, Zheng L, Liu Y. Efficacy and safety of umbilical cord mesenchymal stem cell therapy for rheumatoid arthritis patients: a prospective phase I/II study. Drug Des Devel Ther. 2019; 13:4331-40. https://doi.org/10.2147/DDDT.S225613.

27. Lublin FD, Bowen JD, Huddlestone J, Kremenchutzky M, Carpenter A, Corboy JR, Freedman MS, Krupp L, Paulo C, Hariri RJ, Fischkoff SA. Human placenta-derived cells (PDA-001) for the treatment of adults with multiple sclerosis: a randomized, placebo-controlled, multiple-dose study. Mult Scler Relat Disord. 2014;3(6):696-704. https://doi.org/10.1016/j.msard.2014.08.002.
28. Cai J, Wu Z, Xu X, Liao L, Chen J, Huang L, Wu W, Luo F, Wu C, Pugliese A, Pileggi A, Ricordi C, Tan J. Umbilical cord mesenchymal stromal cell with autologous bone marrow cell transplantation in established type 1 diabetes: a pilot randomized controlled open-label clinical study to assess safety and impact on insulin secretion. Diabetes Care. 2016;39(1):149-57. https://doi. org/10.2337/dc15-0171.

29. Owczarczyk-Saczonek A, Krajewska-Włodarczyk M, Kruszewska A, Placek W, Maksymowicz W, Wojtkiewicz J. Stem cells as potential candidates for psoriasis cell-replacement therapy. Int J Mol Sci. 2017;18(10). https://doi.org/ 10.3390/ijms18102182.

30. Fanouriakis A, Kostopoulou M, Alunno A, Aringer M, Bajema I, Boletis JN, Cervera R, Doria A, Gordon C, Govoni M, Houssiau F, Jayne D, Kouloumas M, Kuhn A, Larsen JL, Lerstrøm K, Moroni G, Mosca M, Schneider M, Smolen JS, Svenungsson E, Tesar V, Tincani A, Troldborg A, van Vollenhoven R, Wenzel J, Bertsias G, Boumpas DT. 2019 update of the EULAR recommendations for the management of systemic lupus erythematosus. Ann Rheum Dis. 2019; 78(6):736-45. https://doi.org/10.1136/annrheumdis-2019-215089.

31. Zhou T, Li H-Y, Liao C, Lin W, Lin S. Clinical efficacy and safety of mesenchymal stem cells for systemic lupus erythematosus. Stem Cells Int. 2020;2020:6518508. https://doi.org/10.1155/2020/6518508.

32. Chernetsky SG, Mont MA, LaPorte DM, Jones LC, Hungerford DS, McCarthy EF. Pathologic features in steroid and nonsteroid associated osteonecrosis. Clin Orthop Relat Res. 1999;368:149-61.

33. Moulton VR, Suarez-Fueyo A, Meidan E, Li H, Mizui M, Tsokos GC. Pathogenesis of human systemic lupus erythematosus: a cellular perspective. Trends Mol Med. 2017;23(7):615-35. https://doi.org/10.1016/j. molmed.2017.05.006.

34. Feng X, Che N, Liu Y, Chen H, Wang D, Li X, Chen W, Ma X, Hua B, Gao X, Tsao BP, Sun L. Restored immunosuppressive effect of mesenchymal stem cells on B cells after olfactory 1/early B cell factor-associated zinc-finger protein down-regulation in patients with systemic lupus erythematosus. Arthritis Rheumatol (Hoboken, NJ). 2014;66(12):3413-23. https://doi.org/10. 1002/art.38879.

35. Feng X, Li R, Huang J, Zhang H, Zhu L, Hua B, Tsao BP, Sun L. Olf1/EBF associated zinc finger protein interfered with antinuclear antibody production in patients with systemic lupus erythematosus. Arthritis Res Ther. 2010;12(2):R59. https://doi.org/10.1186/ar2972.

36. Dhir V, Singh AP, Aggarwal A, Naik S, Misra R. Increased T-lymphocyte apoptosis in lupus correlates with disease activity and may be responsible for reduced T-cell frequency: a cross-sectional and longitudinal study. Lupus. 2009;18(9):785-91. https://doi.org/10.1177/0961203309103152.

37. Gergely P, Grossman C, Niland B, Puskas F, Neupane H, Allam F, Banki K, Phillips PE, Perl A. Mitochondrial hyperpolarization and ATP depletion in patients with systemic lupus erythematosus. Arthritis Rheum. 2002;46(1): 175-90.

38. Chen J, Wang Q, Feng X, Zhang Z, Geng L, Xu T, Wang D, Sun L. Umbilical cord-derived mesenchymal stem cells suppress autophagy of $T$ cells in patients with systemic lupus erythematosus via transfer of mitochondria. Stem Cells Int. 2016;2016:4062789. https://doi.org/10.1155/2016/4062789.

39. Huang S, Wu S, Zhang Z, Deng W, Fan J, Feng R, Kong W, Qi J, Chen W, Tang X, Yao G, Feng X, Wang D, Chen H, Sun L. Mesenchymal stem cells induced CD4+ T cell apoptosis in treatment of lupus mice. Biochem Biophys Res Commun. 2018;507(1-4):30-5. https://doi.org/10.1016/j.bbrc. 2018.10.133.

40. Zhang Z, Huang S, Wu S, Qi J, Li W, Liu S, Cong Y, Chen H, Lu L, Shi S, Wang D, Chen W, Sun L. Clearance of apoptotic cells by mesenchymal stem cells contributes to immunosuppression via PGE2. EBioMedicine. 2019;45: 341-50. https://doi.org/10.1016/j.ebiom.2019.06.016.

41. Wang D, Feng X, Lu L, Konkel JE, Zhang H, Chen Z, Li X, Gao X, Lu L, Shi S, Chen W, Sun L. A CD8 T cell/indoleamine 2,3-dioxygenase axis is required for mesenchymal stem cell suppression of human systemic lupus erythematosus. Arthritis Rheumatol (Hoboken, NJ). 2014;66(8):2234-45. https://doi.org/10.1002/art.38674.

42. Wang D, Wang S, Huang S, Zhang Z, Yuan X, Feng X, Lu L, Sun L. Serum IFN- $\gamma$ predicts the therapeutic effect of mesenchymal stem cells transplantation in systemic lupus erythematosus patients. Stem Cells Transl Med. 2017;6(9):1777-85. https://doi.org/10.1002/sctm.17-0002.

43. Yang L, Wang G, Xia H. Molecular mechanism for impaired suppressive function of Tregs in autoimmune diseases: a summary of cell-intrinsic and cell-extrinsic factors. J Cell Mol Med. 2020. https://doi.org/10.1111/jcmm. 15743. 
44. Togashi Y, Nishikawa H. Regulatory T cells: molecular and cellular basis for immunoregulation. Curr Top Microbiol Immunol. 2017;410. https://doi.org/ 10.1007/82_2017_58.

45. Lee HY, Hong YK, Yun HJ, Kim YM, Kim JR, Yoo WH. Altered frequency and migration capacity of CD4+CD25+ regulatory T cells in systemic lupus erythematosus. Rheumatology (Oxford). 2008;47(6):789-94. https://doi.org/ 10.1093/rheumatology/ken108.

46. Nasef A, Mathieu N, Chapel A, Frick J, François S, Mazurier C, Boutarfa A, Bouchet S, Gorin NC, Thierry D, Fouillard L. Immunosuppressive effects of mesenchymal stem cells: involvement of HLA-G. Transplantation. 2007;84(2): 231-7.

47. Chen C, Liang J, Yao G, Chen H, Shi B, Zhang Z, Zhao C, Zhang H, Sun L. Mesenchymal stem cells upregulate Treg cells via sHLA-G in SLE patients. Int Immunopharmacol. 2017:44:234-41. https://doi.org/10.1016/j.intimp.2017. 01.024.

48. Darlan DM, Munir D, Putra A, Jusuf NK. MSCs-released TGF $\beta 1$ generate CD4CD25Foxp3 in T-reg cells of human SLE PBMC. J Formos Med Assoc. 2020. https://doi.org/10.1016/j.ffma.2020.06.028.

49. Yang J, Chu Y, Yang X, Gao D, Zhu L, Yang X, Wan L, Li M. Th17 and natural Treg cell population dynamics in systemic lupus erythematosus. Arthritis Rheum. 2009:60(5):1472-83. https://doi.org/10.1002/art.24499.

50. Ren S, Hu J, Chen Y, Yuan T, Hu H, Li S. Human umbilical cord derived mesenchymal stem cells promote interleukin-17 production from human peripheral blood mononuclear cells of healthy donors and systemic lupus erythematosus patients. Clin Exp Immunol. 2016;183(3):389-96. https://doi. org/10.1111/cei.12737.

51. Deng W, Chen W, Zhang Z, Huang S, Kong W, Sun Y, Tang X, Yao G, Feng X, Chen W, Sun L. Mesenchymal stem cells promote CD206 expression and phagocytic activity of macrophages through IL-6 in systemic lupus erythematosus. Clin Immunol (Orlando, Fla). 2015;161(2):209-16. https://doi. org/10.1016/j.clim.2015.07.011.

52. Almaani S, Meara A, Rovin BH. Update on lupus nephritis. Clin J Am Soc Nephrol. 2017;12(5):825-35. https://doi.org/10.2215/CJN.05780616.

53. Seo SR, Lee SJ, Park DJ, Kim TJ, Park YW, Lee SS. Successful treatment using cyclosporine in a patient with rhupus complicated by aplastic anemia: a case report and review of the literature. Clin Exp Rheumatol. 2011;29(4):70811.

54. Marks SD, Williams SJ, Tullus K, Sebire NJ. Glomerular expression of monocyte chemoattractant protein-1 is predictive of poor renal prognosis in pediatric lupus nephritis. Nephrol Dial Transplant. 2008;23(11):3521-6. https://doi.org/10.1093/ndt/gfn270

55. Hayashi A, Nagafuchi H, Ito I, Hirota K, Yoshida M, Ozaki S. Lupus antibodies to the HMGB1 chromosomal protein: epitope mapping and association with disease activity. Mod Rheumatol. 2009;19(3):283-92. https://doi.org/10. 1007/s10165-009-0151-7.

56. Gu Z, Akiyama K, Ma X, Zhang H, Feng X, Yao G, Hou Y, Lu L, Gilkeson GS, Silver RM, Zeng $X$, Shi S, Sun L. Transplantation of umbilical cord mesenchymal stem cells alleviates lupus nephritis in MRL/lpr mice. Lupus. 2010;19(13):1502-14. https://doi.org/10.1177/0961203310373782.

57. Zhang Z, Niu L, Tang X, Feng R, Yao G, Chen W, Li W, Feng X, Chen H, Sun L. Mesenchymal stem cells prevent podocyte injury in lupus-prone B6.MRLFaslpr mice via polarizing macrophage into an anti-inflammatory phenotype. Nephrol Dial Transplant. 2019;34(4):597-605. https://doi.org/10. 1093/ndt/gfy 195.

58. Liu J, Lu X, Lou Y, Cai Y, Cui W, Wang J, Nie P, Chen L, Li B, Luo P. Xenogeneic transplantation of human placenta-derived mesenchymal stem cells alleviates renal injury and reduces inflammation in a mouse model of lupus nephritis. Biomed Res Int. 2019;2019:9370919. https://doi.org/10.1155/ 2019/9370919

59. Mai S, Zou L, Tian X, Liao X, Luan Y, Han X, Wei Y, Wu Y, Kuang S, Yang Y, Ma J, Chen Q, Yang J. Double-edged effect of hydroxychloroquine on human umbilical cord-derived mesenchymal stem cells treating lupus nephritis in MRL/lpr mice. Mol Pharm. 2018;15(5):1800-13. https://doi.org/10. 1021/acs.molpharmaceut.7b01146.

60. Smolen JS, Aletaha D, McInnes IB. Rheumatoid arthritis. Lancet. 2016; 388(10055):2023-38. https://doi.org/10.1016/S0140-6736(16)30173-8.

61. Price S. Rheumatoid arthritis: umbilical cord stem cells--the birth of a new treatment for RA? Nat Rev Rheumatol. 2011;7(2):69.

62. Liu Y, Mu R, Wang S, Long L, Liu X, Li R, Sun J, Guo J, Zhang X, Guo J, Yu P, Li C, Liu X, Huang Z, Wang D, Li H, Gu Z, Liu B, Li Z. Therapeutic potential of human umbilical cord mesenchymal stem cells in the treatment of rheumatoid arthritis. Arthritis Res Ther. 2010;12(6):R210. https://doi.org/10. 1186/ar3187.

63. Zhao C, Zhang L, Kong W, Liang J, Xu X, Wu H, Feng X, Hua B, Wang H, Sun L. Umbilical cord-derived mesenchymal stem cells inhibit Cadherin-11 expression by fibroblast-like synoviocytes in rheumatoid arthritis. J Immunol Res. 2015;2015:137695. https://doi.org/10.1155/2015/137695.

64. Ma D, Xu K, Zhang G, Liu Y, Gao J, Tian M, Wei C, Li J, Zhang L. Immunomodulatory effect of human umbilical cord mesenchymal stem cells on T lymphocytes in rheumatoid arthritis. Int Immunopharmacol. 2019; 74:105687. https://doi.org/10.1016/j.intimp.2019.105687.

65. Chen G, Ye Y, Cheng M, Tao Y, Zhang K, Huang Q, Deng J, Yao D, Lu C, Huang Y. Quercetin combined with human umbilical cord mesenchymal stem cells regulated tumour necrosis factor-a/interferon- $\gamma$-stimulated peripheral blood mononuclear cells activation of toll-like receptor 3 signalling. Front Pharmacol. 2020;11:499. https://doi.org/10.3389/fphar.2020. 00499.

66. Greish S, Abogresha N, Abdel-Hady Z, Zakaria E, Ghaly M, Hefny M. Human umbilical cord mesenchymal stem cells as treatment of adjuvant rheumatoid arthritis in a rat model. World J Stem Cells. 2012;4(10):101-9. https://doi.org/10.4252/wjsc.v4.i10.101.

67. Udalova IA, Mantovani A, Feldmann M. Macrophage heterogeneity in the context of rheumatoid arthritis. Nat Rev Rheumatol. 2016;12(8):472-85. https://doi.org/10.1038/nrrheum.2016.91.

68. Shin T-H, Kim H-S, Kang T-W, Lee B-C, Lee H-Y, Kim Y-J, Shin J-H, Seo Y, Won Choi S, Lee S, Shin K, Seo K-W, Kang K-S. Human umbilical cord bloodstem cells direct macrophage polarization and block inflammasome activation to alleviate rheumatoid arthritis. Cell Death Dis. 2016;7(12):e2524. https://doi.org/10.1038/cddis.2016.442.

69. Dobson R, Giovannoni G. Multiple sclerosis - a review. Eur J Neurol. 2019; 26(1):27-40. https://doi.org/10.1111/ene.13819.

70. Correale J, Gaitán MI, Ysrraelit MC, Fiol MP. Progressive multiple sclerosis: from pathogenic mechanisms to treatment. Brain. 2017;140(3):527-46. https://doi.org/10.1093/brain/aww258.

71. Donders R, Vanheusden M, Bogie JFJ, Ravanidis S, Thewissen K, Stinissen P, Gyselaers W, Hendriks JJA, Hellings N. Human Wharton's jelly-derived stem cells display immunomodulatory properties and transiently improve rat experimental autoimmune encephalomyelitis. Cell Transplant. 2015;24(10): 2077-98. https://doi.org/10.3727/096368914X685104.

72. Liu R, Zhang Z, Lu Z, Borlongan C, Pan J, Chen J, Qian L, Liu Z, Zhu L, Zhang J, Xu Y. Human umbilical cord stem cells ameliorate experimental autoimmune encephalomyelitis by regulating immunoinflammation and remyelination. Stem Cells Dev. 2013;22(7):1053-62. https://doi.org/10.1089/ scd.2012.0463.

73. Liu S, Wang J, Han R, Meng M, Wang W, Zhao Y, Yang F, Yang L, Gao H, Zhao Y, Yang L, Wang R, Tang W, Li Y, Duan S, Wang J, He Z, Li L, Hou Z. Therapeutic effect of transplanted umbilical cord mesenchymal stem cells in a cynomolgus monkey model of multiple sclerosis. Am J Transl Res. 2019; 11(4):2516-31.

74. Spiegel S, Milstien S. The outs and the ins of sphingosine-1-phosphate in immunity. Nat Rev Immunol. 2011;11(6):403-15. https://doi.org/10.1038/ nri2974.

75. Wang Y-L, Xue P, Xu C-Y, Wang Z, Liu X-S, Hua L-L, Bai H-Y, Zeng Z-L, Duan H-F, Li J-F. SPK1-transfected UCMSC has better therapeutic activity than UCMSC in the treatment of experimental autoimmune encephalomyelitis model of multiple sclerosis. Sci Rep. 2018;8(1):1756. https://doi.org/10.1038/ s41598-018-19703-5.

76. Zhang L, Wang X, Lu X, Ma Y, Xin X, Xu X, Wang S, Hou Y. Tetramethylpyrazine enhanced the therapeutic effects of human umbilical cord mesenchymal stem cells in experimental autoimmune encephalomyelitis mice through Nrf2/HO-1 signaling pathway. Stem Cell Res Ther. 2020;11(1):186. https://doi.org/10.1186/s13287-020-01700-z.

77. Bravo B, Gallego Ml, Flores Al, Bornstein R, Puente-Bedia A, Hernández J, de la Torre P, García-Zaragoza E, Perez-Tavarez R, Grande J, Ballester A, Ballester S. Restrained Th17 response and myeloid cell infiltration into the central nervous system by human decidua-derived mesenchymal stem cells during experimental autoimmune encephalomyelitis. Stem Cell Res Ther. 2016;7:43. https://doi.org/10.1186/s13287-016-0304-5.

78. Fisher-Shoval Y, Barhum Y, Sadan O, Yust-Katz S, Ben-Zur T, Lev N, Benkler C, Hod M, Melamed E, Offen D. Transplantation of placenta-derived mesenchymal stem cells in the EAE mouse model of MS. J Mol Neurosci. 2012;48(1):176-84. https://doi.org/10.1007/s12031-012-9805-6. 
79. Selim AO, Selim SA, Shalaby SM, Mosaad H, Saber T. Neuroprotective effects of placenta-derived mesenchymal stromal cells in a rat model of experimental autoimmune encephalomyelitis. Cytotherapy. 2016;18(9):110013. https://doi.org/10.1016/j.jcyt.2016.06.002.

80. Jiang H, Zhang Y, Tian K, Wang B, Han S. Amelioration of experimental autoimmune encephalomyelitis through transplantation of placental derived mesenchymal stem cells. Sci Rep. 2017;7:41837. https://doi.org/10. 1038/srep41837.

81. Shapira I, Fainstein N, Tsirlin M, Stav I, Volinsky E, Moresi C, Ben-Hur T, Gorodetsky R. Placental stromal cell therapy for experimental autoimmune encephalomyelitis: the role of route of cell delivery. Stem Cells Transl Med. 2017;6(4):1286-94. https://doi.org/10.5966/sctm.20150363.

82. Tian K-W, Zhang $Y-Y$, Jiang H, Han S. Intravenous C16 and angiopoietin-1 improve the efficacy of placenta-derived mesenchymal stem cell therapy for EAE. Sci Rep. 2018;8(1):4649. https://doi.org/10. 1038/s41598-018-22867-9.

83. Greb JE, Goldminz AM, Elder JT, Lebwohl MG, Gladman DD, Wu JJ, Mehta NN, Finlay AY, Gottlieb AB. Psoriasis. Nat Rev Dis Primers. 2016;2:16082. https://doi.org/10.1038/nrdp.2016.82.

84. Chen M, Peng J, Xie Q, Xiao N, Su X, Mei H, Lu Y, Zhou J, Dai Y, Wang S, Li C, Lin G, Cheng L. Mesenchymal stem cells alleviate moderate-to-severe psoriasis by reducing the production of type I interferon (IFN-I) by plasmacytoid dendritic cells (pDCs). Stem Cells Int. 2019;2019:6961052 https://doi.org/10.1155/2019/6961052.

85. Lee YS, Sah SK, Lee JH, Seo K-W, Kang K-S, Kim T-Y. Human umbilical cord blood-derived mesenchymal stem cells ameliorate psoriasis-like skin inflammation in mice. Biochem Biophys Rep. 2017;9:281-8. https://doi.org/ 10.1016/j.bbrep.2016.10.002.

86. Imai Y, Yamahara K, Hamada A, Fujimori Y, Yamanishi K. Human amnionderived mesenchymal stem cells ameliorate imiquimod-induced psoriasiform dermatitis in mice. J Dermatol. 2019;46(3):276-8. https://doi. org/10.1111/1346-8138.14768.

87. van Ginkel MS, Glaudemans AWJM, van der Vegt B, Mossel E, Kroese FGM, Bootsma H, Vissink A. Imaging in primary Sjögren's syndrome. J Clin Med. 2020;9(8). https://doi.org/10.3390/jcm9082492.

88. Liu R, Su D, Zhou M, Feng X, Li X, Sun L. Umbilical cord mesenchymal stem cells inhibit the differentiation of circulating $T$ follicular helper cells in patients with primary Sjögren's syndrome through the secretion of indoleamine 2,3-dioxygenase. Rheumatology (Oxford). 2015;54(2):332-42. https://doi.org/10.1093/rheumatology/keu316.

89. Matsui K, Sano H. T helper 17 cells in primary Sjögren's syndrome. J Clin Med. 2017;6(7). https://doi.org/10.3390/jcm6070065.

90. Alunno A, Montanucci P, Bistoni O, Basta G, Caterbi S, Pescara T, Pennoni I, Bini V, Bartoloni E, Gerli R, Calafiore R. In vitro immunomodulatory effects of microencapsulated umbilical cord Wharton jelly-derived mesenchymal stem cells in primary Sjögren's syndrome. Rheumatology (Oxford). 2015;54(1):1638. https://doi.org/10.1093/rheumatology/keu292.

91. Liu Y, Li C, Wang S, Guo J, Guo J, Fu J, Ren L, An Y, He J, Li Z. Human umbilical cord mesenchymal stem cells confer potent immunosuppressive effects in Sjögren's syndrome by inducing regulatory T cells. Mod Rheumatol. 2020. https://doi.org/10.1080/14397595.2019.1707996.

92. Vinuesa CG, Linterman MA, Yu D, MacLennan ICM. Follicular helper T cells. Annu Rev Immunol. 2016;34:335-68. https://doi.org/10.1146/annurevimmunol-041015-055605.

93. X-y L, Wu Z-b, Ding J, Zheng Z-h, X-y L, L-n C, Zhu P. Role of the frequency of blood CD4(+) CXCR5(+) CCR6(+) T cells in autoimmunity in patients with Sjögren's syndrome. Biochem Biophys Res Commun. 2012;422(2):238-44. https://doi.org/10.1016/j.bbrc.2012.04.133.

94. Zhou D, McNamara NA. Macrophages: important players in primary Sjögren's syndrome? Expert Rev Clin Immunol. 2014;10(4):513-20. https:// doi.org/10.1586/1744666X.2014.900441.

95. Lu X, Li N, Zhao L, Guo D, Yi H, Yang L, Liu X, Sun D, Nian H, Wei R. Human umbilical cord mesenchymal stem cells alleviate ongoing autoimmune dacryoadenitis in rabbits via polarizing macrophages into an antiinflammatory phenotype. Exp Eye Res. 2020;191:107905. https://doi.org/10. 1016/j.exer.2019.107905.

96. Yang C, Chen Y, Li F, You M, Zhong L, Li W, Zhang B, Chen Q. The biological changes of umbilical cord mesenchymal stem cells in inflammatory environment induced by different cytokines. Mol Cell Biochem. 2018;446(1-2):171-84. https://doi.org/10.1007/s11010-018-3284-1.
97. Villani V, Milanesi A, Sedrakyan S, Da Sacco S, Angelow S, Conconi MT, Di Liddo R, De Filippo R, Perin L. Amniotic fluid stem cells prevent $\beta$-cell injury. Cytotherapy. 2014;16(1):41-55. https://doi.org/10.1016/j.jcyt.2013.08.010.

98. Wang $R$, Zhang D, Zhang T, Zhao F, Lang H, Lin X, Pang X. The differentiation of human MSCs derived from adipose and amniotic tissues into insulin-producing cells, induced by PEI@Fe3O4 nanoparticles-mediated NRSF and SHH silencing. Int J Mol Med. 2018;42(5):2831-8. https://doi.org/ 10.3892/ijmm.2018.3827.

99. Kim J, Park S, Kang HM, Ahn CW, Kwon HC, Song JH, Lee YJ, Lee KH, Yang H, Baek SY, Yoo SH, Kim SH, Kim H. Human insulin secreted from insulinogenic xenograft restores normoglycemia in type 1 diabetic mice without immunosuppression. Cell Transplant. 2012;21(10):2131-47. https:// doi.org/10.3727/096368912X636803.

100. Mu X-P, Ren L-Q, Yan H-W, Zhang X-M, Xu T-M, Wei A-H, Jiang J-L. Enhanced differentiation of human amniotic fluid-derived stem cells into insulin-producing cells in vitro. J Diabetes Investig. 2017;8(1):34-43. https:// doi.org/10.1111/jdi.12544.

101. Wang D, Zhang H, Liang J, Wang H, Hua B, Feng X, Gilkeson GS, Farge D, Shi S, Sun L. A long-term follow-up study of allogeneic mesenchymal stem/ stromal cell transplantation in patients with drug-resistant systemic lupus erythematosus. Stem Cell Reports. 2018;10(3):933-41. https://doi.org/10. 1016/j.stemcr.2018.01.029.

102. Liang J, Zhang H, Kong W, Deng W, Wang D, Feng X, Zhao C, Hua B, Wang $H$, Sun L. Safety analysis in patients with autoimmune disease receiving allogeneic mesenchymal stem cells infusion: a long-term retrospective study. Stem Cell Res Ther. 2018;9(1):312. https://doi.org/10.1186/s13287-0181053-4.

103. Wang D, Niu L, Feng X, Yuan X, Zhao S, Zhang H, Liang J, Zhao C, Wang H, Hua B, Sun L. Long-term safety of umbilical cord mesenchymal stem cells transplantation for systemic lupus erythematosus: a 6-year follow-up study. Clin Exp Med. 2017;17(3):333-40. https://doi.org/10.1007/s10238-016-0427-0.

104. Wang D, Huang S, Yuan X, Liang J, Xu R, Yao G, Feng X, Sun L. The regulation of the Treg/Th17 balance by mesenchymal stem cells in human systemic lupus erythematosus. Cell Mol Immunol. 2017;14(5):423-31. https:// doi.org/10.1038/cmi.2015.89.

105. Wang D, Li J, Zhang Y, Zhang M, Chen J, Li X, Hu X, Jiang S, Shi S, Sun L. Umbilical cord mesenchymal stem cell transplantation in active and refractory systemic lupus erythematosus: a multicenter clinical study. Arthritis Res Ther. 2014;16(2):R79. https://doi.org/10.1186/ar4520.

106. Gu F, Wang D, Zhang H, Feng X, Gilkeson GS, Shi S, Sun L. Allogeneic mesenchymal stem cell transplantation for lupus nephritis patients refractory to conventional therapy. Clin Rheumatol. 2014;33(11):1611-9. https://doi.org/10.1007/s10067-014-2754-4.

107. Alunno A, Bistoni O, Montanucci P, Basta G, Calafiore R, Gerli R. Umbilical cord mesenchymal stem cells for the treatment of autoimmune diseases: beware of cell-to-cell contact. Ann Rheum Dis. 2018;77(3):e14. https://doi. org/10.1136/annrheumdis-2017-211790.

108. Park EH, Lim H-S, Lee S, Roh K, Seo K-W, Kang K-S, Shin K. Intravenous infusion of umbilical cord blood-derived mesenchymal stem cells in rheumatoid arthritis: a phase la clinical trial. Stem Cells Transl Med. 2018;7(9): 636-42. https://doi.org/10.1002/sctm.18-0031.

109. Wang L, Wang L, Cong X, Liu G, Zhou J, Bai B, Li Y, Bai W, Li M, Ji H, Zhu D, Wu M, Liu Y. Human umbilical cord mesenchymal stem cell therapy for patients with active rheumatoid arthritis: safety and efficacy. Stem Cells Dev. 2013;22(24):3192-202. https://doi.org/10.1089/scd.2013.0023.

110. Chen H, Niu J-W, Ning H-M, Pan X, Li X-B, Li Y, Wang D-H, Hu L-D, Sheng H$X$, Xu M, Zhang L, Zhang B. Treatment of psoriasis with mesenchymal stem cells. Am J Med. 2016;129(3):e13-4. https://doi.org/10.1016/j.amjmed.2015. 11.001 .

111. Hu J, Yu X, Wang Z, Wang F, Wang L, Gao H, Chen Y, Zhao W, Jia Z, Yan S, Wang $Y$. Long term effects of the implantation of Wharton's jelly-derived mesenchymal stem cells from the umbilical cord for newly-onset type 1 diabetes mellitus. Endocr J. 2013;60(3):347-57.

112. Wu X, Jiang J, Gu Z, Zhang J, Chen Y, Liu X. Mesenchymal stromal cell therapies: immunomodulatory properties and clinical progress. Stem Cell Res Ther. 2020;11(1):345. https://doi.org/10.1186/s13287-020-01855-9.

113. Maacha S, Sidahmed H, Jacob S, Gentilcore G, Calzone R, Grivel J-C, Cugno C. Paracrine mechanisms of mesenchymal stromal cells in angiogenesis. Stem Cells Int. 2020;2020:4356359. https://doi.org/10.1155/2020/4356359.

114. Yang ZX, Han ZB, Ji YR, Wang YW, Liang L, Chi Y, Yang SG, Li LN, Luo WF, Li JP, Chen DD, Du WJ, Cao XC, Zhuo GS, Wang T, Han ZC. CD106 identifies a 
subpopulation of mesenchymal stem cells with unique immunomodulatory properties. PLoS One. 2013;8(3):e59354. https://doi.org/10.1371/journal.pone. 0059354.

115. Moll G, Ankrum JA, Kamhieh-Milz J, Bieback K, Ringdén O, Volk H-D, Geissler $S$, Reinke P. Intravascular mesenchymal stromal/stem cell therapy product diversification: time for new clinical guidelines. Trends Mol Med. 2019;25(2): 149-63. https://doi.org/10.1016/j.molmed.2018.12.006.

\section{Publisher's Note}

Springer Nature remains neutral with regard to jurisdictional claims in published maps and institutional affiliations. 